\title{
A ocupação irregular como estratégia de conquista da cidade. Enfoque sobre os aspectos territoriais do problema em Porto Alegre ${ }^{1}$
}

\author{
Álvaro Luiz Heidrich \\ Amanda Cristina Bahi de Souza \\ Christiano Correa Teixeira \\ Marilia Guimarães Rathmann \\ Rodrigo Costa de Aguiar
}

\section{INTRODUÇÃO}

Este texto expõe nossa compreensão sobre os problemas das ocupações irregulares, tendo a cidade de Porto Alegre como campo de observação empírica. A pesquisa em que essas observações se apoiam buscou caracterizar aspectos da formação dessas ocupações em duas escalas: o âmbito geral das áreas de ocupação irregular no município ${ }^{2}$ e de cinco casos em diferentes localizações no contexto socioespacial da cidade ${ }^{3}$.

Para o estudo do contexto geral do município, recorreu-se às análises cartográfica e documental, em articulação aos estudos do espaço social da cidade. Já para o estudo das situações selecionadas, o trabalho de campo com registros textuais e fotográficos, combinados com a realização de entrevistas de abordagem qualitativa, permitiu a composição de diários de campo para sua posterior análise.

1 Este texto traz reflexões e resultados da pesquisa "O território da ocupação: formação, cotidiano e relações com a cidade", desenvolvido no período de 2008-2011 e integrante do projeto "Estruturação territorial, dinâmica socioespacial e governança: Efeitos sociais e processos de transformação nas Aglomerações Urbanas do Rio Grande do Sul - 1991/2010”, do núcleo Porto Alegre do Observatório das Metrópoles. Pesquisa realizada com fomento CNPq e FAPERGS.

2 Os dados oficiais utilizados para as análises das áreas de ocupação tiveram referência no estudo de Aldovan de Oliveira Moraes (1999 e 2000) e a base de dados do Departamento Municipal de Habitação (DEMHAB), da Prefeitura Municipal de Porto Alegre. Igualmente, a caracterização do espaço social de Porto Alegre tem o ano de 2000 como referência, tomado a partir do estudo de Mammarella e Barcellos (2005).

3 A busca pela compreensão da territorialidade dessas unidades irregulares de ocupação levou a um estudo baseado em levantamento de campo em cinco vilas irregulares em Porto Alegre, distribuídas espacialmente na malha urbana de Porto Alegre. O levantamento de campo considerou as vilas irregulares Icaraí II, Chocolatão, Areia, Minuano e Invasão (da Restinga). 
Esses procedimentos estiveram articulados ao enfoque teórico-metodológico da Geografia Social, um campo de estudos que considera a imbricação das relações sociais e espaciais. Ele refere-se ao espaço, transformado em território pelas representações de identidade e ações sociopolíticas, assim como registra todas as contingências do ambiente geográfico e os efeitos da economia e das técnicas (DI MÉO, 1998).

A cidade de Porto Alegre caracteriza-se como espaço metropolitano no contexto da produção e reprodução do capitalismo, uma condição que confere maior tensão às dinâmicas urbanas, dado que a ocupação e o uso do solo se delineiam em espaços mais "apertados", muito disputados. O espaço faltante para as diversas buscas da centralização, da oferta de serviços e da aglutinação do mercado torna o que se dispõe, em geral, muito mais caro, tendo-se em conta que, para residir e usufruir da cidade, necessita-se da mediação do mercado de imóveis. Em vista disso, a discussão que segue orienta-se especialmente para a compreensão da constituição dos espaços de busca do que a cidade oferece por parte daqueles que não dispõem de recursos para participar dessa mediação.

Por ocupação irregular compreendemos a apropriação de parcela do solo urbano para constituir moradia de maneira informal, quer dizer, sem a intermediação regular do mercado de imóveis ou programas habitacionais. Quase sempre esse processo é formador de vilas populares e favelas. São compostas muitas vezes por habitações precárias, como é característica comum no início das ocupações. Outro traço que configura sua constituição é a autoconstrução, uma prática que economiza fatores na produção da moradia mediante o uso da própria força de trabalho do morador (MARICATO, 1979). No estudo desenvolvido por Aldovan de Oliveira Moraes, essas áreas são denominadas por núcleos ou vilas irregulares e definidas pelo conjunto de moradias em áreas públicas ou privadas, que apresentam problemas de irregularidade fundiária e deficiências de infraestrutura e serviços urbanos (MORAES, 2007).

Em linguagem difundida, usada muito na imprensa, mas também com uso popular não desprezível e já com registro em dicionário ${ }^{4}$, tais espaços são denominados “invasão". Todavia, não entendemos ser este o termo mais apropriado, por estar diretamente associado à ótica da propriedade do solo regulamentada, pública ou privada, o que, portanto, limita-se a apenas essa face da questão. Para enfatizar o sentido sociogeográfico de considerar a condição mais geral de preenchimento do espaço geográfico, o termo ocupação - que aqui associamos ao irregular - reforça a ideia de fixação e permanência, tão presente e comum nas cidades brasileiras e latino-americanas e que, no mais das vezes, diz respeito à tomada da posse de parcelas sem marca de uso ou destinação ${ }^{5}$. Considera, então, também o lado dos

4 Dicionário Aurélio: Local ocupado ilegalmente por habitações populares (FERREIRA, 2004).

5 Conforme o mesmo dicionário: Ato de apoderar-se alguém, legalmente, de coisa móvel (ou semovente) sem dono, ou porque ainda não foi apropriada, ou por haver sido abandonada (FERREIRA, 2004). 
que percebem esse aspecto e passam a lhe dar destino para a moradia.Em 10 de julho de 2001, sob a Lei 10.257, foi instituído o Estatuto da Cidade, o qual "agregou a ordem urbanística no rol de direitos metaindividuais [...] com o fim de garantir a implementação de suas diretrizes, institutos e instrumentos de ordenação legal” (SILVA, 2011, p. 308). Com efeito, o direito à cidade incorpora, juridicamente, o mesmo patamar dos direitos difusos e coletivos, como o direito do consumidor e do patrimônio histórico, por exemplo. Então, a função social da cidade busca sobrepor o coletivo sobre o individual, e efetivar o "uso socialmente justo do espaço urbano [...] democratizando os espaços de poder, de produção e de cultura” (SILVA, 2011, p. 309). Considerando o direito à cidade como previsto no ordenamento jurídico, o caso das ocupações irregulares, que se multiplicam em todas as grandes (e médias) cidades brasileiras, também é contemplado.No entanto, o que se verifica na prática não é uma harmoniosa coexistência entre os interesses privados e sociais. A figura das construtoras e incorporadoras - que nos últimos anos tem se beneficiado dos programas públicos de construção de moradias populares, como Minha Casa, Minha Vida - é a de um agente que especula com o solo urbano; e com o mercado aquecido e a crescente demanda por moradias, fruto da facilidade de crédito, essa figura pressiona poráreas ocupadas irregularmente ou no deslocamento de tais comunidades para áreas distantes de seus empreendimentos. Então, o que temos presenciado, principalmente no caso de Porto Alegre, é uma tensão entre os movimentos sociais e as construtoras.

Ainda que tenhamos uma normativa jurídica para o assentamento de famílias em situação irregular, o que se verifica é uma crescente busca pela centralidade urbana, por meio das ocupações irregulares. Conforme divulgado pela Corregedoria Geral da Justiça do $\mathrm{RS}^{\mathbf{6}}$, somente na cidade de Porto Alegre, até o mês de setembro de 2014, havia 2.364 ações de reintegração de posse. O que evidencia uma disputa por espaço e território. Se de um lado temos as construtoras, que incessantemente buscam novas áreas para seus empreendimentos, de outro, temos os movimentos sociais e as comunidades auto-organizadas, que desenvolvem uma rede de informações sobre as novas áreas a serem ocupadas. Essas disputas por áreas, que por vezes não entram na esfera judicial, tornam flagrantes que a questão da moradia e o direito à cidade são batalhas travadas diuturnamente. Com efeito, essas lutas geram tensões que se estendem aos territórios, pois a acepção do termo vai além do valor de troca, ela traz consigo o valor de uso, as marcas do vivido (HAESBAERT, 2008).

Em função dessas qualificações, as áreas formadas por ocupação irregular devem ser, desse modo, consideradas como territórios. Há uma razão fundamental para isso: mesmo que a sua produção deva ser concebida num quadro relacional,

6 Cf. Zero Hora, edição de 17/09/2014, disponível em: <http://zh.clicrbs.com.br/rs/noticias/ noticia/2014/09/justica-tem-2-364-processos-de-reintegracao-de-posse-em-porto-alegre-4599766. html>. Acesso em: 10 de out. de 2014. 
integrante da produção do espaço urbano, trata-se também de um tipo de relação mais universal com o espaço, da ação de tomá-lo em posse e utilizar isso como uma estratégia de conquista. Essa é uma significação clássica deste conceito, de apropriação como uma estratégia em busca de controle ou conquista de recursos, como observou Robert Sack (1986). Mas, por outro lado, aspectos que dizem respeito à territorialidade humana, como espaços definidos por formulações identitárias vão se evidenciar junto às populações dos moradores dessas áreas. A prática e o viver coletivo colaboram para isso ${ }^{7}$.

Por outro lado, o próprio espaço urbano é fortemente territorializado, com múltiplas áreas demarcadas, de regramento funcional e de usos consolidados. Mesmo assim, é também espaço sujeito à apropriação, posto que a territorialização não desfaz a condição primeira e original de espaço. E, como territórios derivam do poder (dos poderes), haverá sempre a possibilidade da sua constituição, em oposição e alternativa ao já estabelecido (HEIDRICH; HEIDRICH, 2010). Numa sociedade em conflito, isso não se faz sem tensão. Assim, do lado da cidade, ações como contenção, remoção, regularização fundiária também constituem prática territorial, à medida que se produzem espaços controlados, extinguidos, transformados ou incorporados no espaço social e geográfico da cidade.

Esses problemas estão sujeitos ao modo como nos relacionamos em sociedade e ordenamos o uso do espaço urbano, modo esse que compreende, de um lado, dinâmicas autônomas de reprodução econômica e, de outro, ações que visam o estabelecimento de um espaço urbano por meio de uma ordem política. Todavia, esse ordenamento não tem garantido solução aos problemas que se agregam à constituição da cidade. Esse quadro expressa, justo porque o produz, uma geografia de espaços segregados, mais distantes dos benefícios que a cidade proporciona. Compreendemos isso com o respaldo do argumento de Henri Lefebvre como uma contradição do espaço (2008 [1972]), pois enquanto numa direção se produz a centralização de recursos e possibilidades diversas que se oferecem a todos, noutra direção não se contemplam todas as demandas por seus atributos.

Para o encaminhamento dessa discussão, o texto que segue estrutura-se em três tópicos: uma discussão sobre a situação geral em contexto, com ênfase no espaço social da cidade; uma apresentação geral da ocupação "irregular" e comentários e análises sobre as áreas de ocupação selecionadas, num esforço de diálogo entre teoria e prática; e considerações resultantes das observações da pesquisa realizada.

\footnotetext{
7 Além do mais clássico estudo sobre e as territorialidades humanas, de Roberto Sack (1986), há uma rica bibliografia sobre esse enfoque da territorialidade humana, que explora a sua constituição elaborada pelos aspectos imateriais da cultura, as ideologias, os discursos, a identidade. Muito embora não nos tenhamos reportado a muitos, os seguintes estudos são inspiradores da abordagem aqui adotada: DI MÉO; BULÉON (2007); DI MÉO (1996; 1998); HAESBAERT (2004); RAFFESTIN (1987); SAQUET; SPOSITO (2009); SAQUET (2007); SOUZA (1995 e 2001).
} 


\section{AS OCUPAÇÕES IRREGULARES NO CONTEXTO SOCIOESPACIAL DA CIDADE}

A cidade, como uma forma da espacialidade, além de seus aspectos estruturados, paisagens e materializações consolidadas, compreende também as relações de um coletivo. Com esse sentido, Raymond Ledrut (1974 [1968]) a vê como uma comunidade territorial:

Por certo, tais relações se estabelecem mediante a espacialidade, isto é, por meio das coisas que formam determinado espaço, e isto ao menos na mesma medida em que o fazem por meio da linguagem. Assim mesmo, se constituem sobre a base da espacialidade. Mas o espaço somente tem significado em relação à vida coletiva dos homens que ocupam os lugares. (...) Por conseguinte, a cidade não é uma coisa, um objeto; nem sequer uma máquina que deva funcionar com fluidez; é uma comunidade humana, uma coletividade territorial, uma população estabelecida de maneira mais ou menos duradoura em um espaço até certo ponto bem delimitado, cujos membros mantêm relações de interdependência regidas por determinadas instituições (p. 23-24).

É um espaço com particulares atributos de um modo de viver urbano, pessoas e grupos com vidas particulares e interdependentes, articuladas por relações e instituições típicas, nascidas e próprias desse meio. É o que se vive, mas também uma situação idealizada, planejada de acordo com um ordenamento político sob os efeitos das relações econômicas. É difícil admitir que existam espaços do urbano que estejam alijados dos benefícios dessa própria situação. $\mathrm{O}$ problema é que esse qualitativo do urbano em boa medida se expressa fragmentariamente: é paisagem, porque é um compósito de tudo o que se manifesta, mas por também compor territórios com suas definições de uso e acesso não permite a toda sua população o usufruto de tudo que está em paisagem. Desse modo, o espaço que contém ambas essas feições expressa o que há em sua inteira contradição.

As áreas de ocupação irregular constituem a materialização no espaço das ações de sujeitos que pretendem pertencer à cidade, usufruir de seus atributos. Porém, a simples localização na cidade não dá a seus ocupantes a plenitude desse usufruto, embora seja um caminho para isso. O espaço urbano, em sua concretude, é impregnado de desigualdades. Espaços “nobres”, bairros de classes endinheiradas, médias e populares etc., de policentrismos, de fraturas socioespaciais e de periferias. Esses espaços compõem o conjunto no qual cada grupo se encontra "acantonado numa posição ou numa classe precisa de posições vizinhas, quer dizer, numa região determinada do espaço" (BOURDIEU, 1989, p. 134), que agrega todos os seus atributos, como renda, instrução, atividade ocupacional, relações institucionais, conhecimento formal e simbólico.

O estudo desse espaço social em Porto Alegre, obtido por meio da tipologia socioespacial, que considera fundamentalmente a composição do território por 
categorias socio-ocupacionais ${ }^{8}$, revela uma cidade ocupada por quatro categorias, representativas de suas respectivas posições no espaço social: superior, médio, operário e popular (Figura 1).

O tipo superior é o lugar da predominância das elites. Na área que ocupa se concentram as moradias das classes dirigentes e dos intelectuais, embora nelas também seja significativa a presença de camadas médias. A Geografia dessa posição conforma uma distribuição em duas regiões. A mais adensada compreende o centro da cidade como no "vértice de um leque" que conforma toda a mancha urbana de Porto Alegre, área que apresenta também o adensamento dos serviços e infraestruturas da cidade. Nessa área, como em suas adjacências, conforma-se uma paisagem de meio urbano de forte centralidade e concentração dos atributos da urbanidade. Uma segunda área, mais ao sul, é região com presença, embora não exclusiva, de bairros seletos de alta-renda. Nessas áreas há, em grau menos expressivo, a localização de ocupações profissionais médias. Nesses espaços as áreas de ocupação irregular são rarefeitas, fato coerente com o valor mais elevado do solo urbano e, com evidência, a mais intensa ocupação formal e regular desse espaço.

Na estruturação do tipo médio, em que prevalece a presença das ocupações de pessoal de escritório, atividades de supervisão, ocupações técnicas, nível médio de saúde e educação etc. também se encontra a presença variada de todas as ocupações, tendo-se em conta que a característica mais forte é a menor participação das camadas operárias. Esse tipo se distribui no entorno do anterior, revelando também, nesse aspecto, sua condição mediana no que diz respeito ao usufruto das vantagens locacionais da disposição dos serviços e infraestruturas. É nessas áreas que se projetam os principais eixos de expansão urbana da cidade, como diagnosticou Sanfelice (2009). Mas é também junto a essa categoria que ocorre a maior incidência da ocupação irregular. Há aí mais urbanidade em formação, onde se encontra junto a cursos d'água e áreas com declividade acentuada, terrenos originalmente não destinados à produção de moradias e, também, terrenos em reserva de valor.

No tipo operário, predominam os trabalhadores do secundário tradicional e moderno (trabalhadores do secundário, do terciário especializado, operários da construção civil e serviços auxiliares) e popular, mas também há presença das mesmas

8 Cf. Mammarella e Barcellos (2005) e Mammarella (2008), consideraram-se os critérios (a) distribuição da população, (b) continuidade e contiguidade geográfica, (c) unidades urbanísticas e (d) correspondência entre áreas e seus limites para agregação dos dados. Ver também Mammarella e Barcellos, "Uma abordagem tipológica da estrutura socioespacial da Região Metropolitana de Porto Alegre" (2009). O argumento fundamental dessa metodologia baseia-se na forte correlação entre as hierarquias das posições ocupacionais e das posições dos ocupados na escala de distribuição do capital escolar e econômico no espaço social das metrópoles de São Paulo, Rio de Janeiro e Belo Horizonte (RIBEIRO e LAGO, 2000). No capítulo 2 desse livro, apresenta-se análise desse quadro para as aglomerações urbanas do Rio grande do Sul com base nos dados do censo de 2010. Contudo, aqui neste capítulo, optamos por preservar a análise com base nos dados do censo de 2000, a fim de mantermos coerência com o levantamento das áreas de ocupação irregular elaborado pelo DEMHAB. 
Figura 1: Porto Alegre. Tipologia socioespacial.

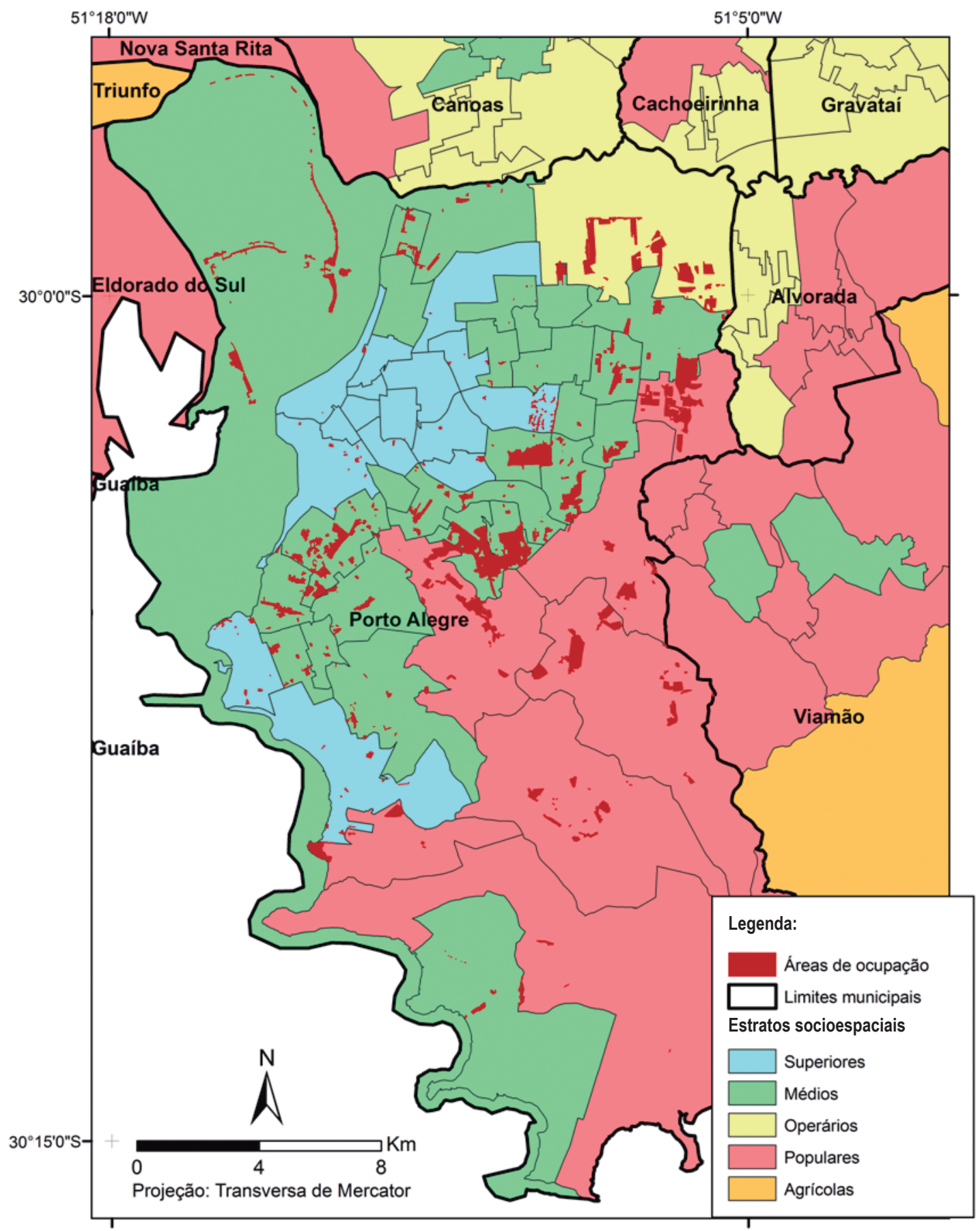

Fonte dos dados: MORAES (1999), Bases Cartográficas do DEMHAB, MAMMARELLA; BARCELOS; 2005. 
ocupações profissionais do tipo popular. Em menor quantidade, encontra-se a presença de ocupações médias. E, no tipo popular, nota-se a presença predominante dos trabalhadores do terciário não especializado, como os empregados domésticos e secundariamente, do terciário especializado. Esses dois tipos socioespaciais formam, em sequência à distribuição dos anteriores, uma extensa área em direção ao periférico. Conformam duplamente a periferia: geográfica e socioeconômica: o espaço mais distante dos centros de comércio ou negócio com notável carência ou precariedade de infraestrutura. Como bem concebeu Ermínia Maricato (1979, p. 83):

Essa ocupação é urbana, mas pode-se dizer também que é desurbanizada à luz de certas formulações técnicas urbanísticas de planejamento ou mesmo à luz de certas formulações antropológicas, ou ainda à luz da história das cidades?

Os diferentes tipos se distribuem geograficamente de modo bastante coeso quase sem descontinuidades e demonstram forte coerência entre as posições mais bem ocupadas do espaço social (como renda, prestígio, instrução etc.) e a distribuição da materialidade da urbanidade, como meios de consumo coletivos, a centralidade, a melhor infraestrutura urbana, assim como, reciprocamente, opostamente, a precariedade e a falta desses aributos.

Até as mudanças mais recentes das estratégias de reprodução do capital imobiliário e das modalidades da produção das moradias de classes alta e média há um histórico de inexpressividade da ocorrência das moradias das camadas superiores junto ao espaço de predomínio do tipo popular, demarcando-se a separação das classes sociais geograficamente, como já haviam observado Mammarella e Barcellos (2005). Todavia, tal segregação vem sendo aos poucos acrescida de novas feições, como a fratura socioespacial que "avizinha" profundas diferenças sociais, mantendose o distanciamento socioespacial por meio dos aparatos técnicos dos condomínios horizontais fechados (HEIDRICH, 2007). Compreende-se, de acordo com o conceito base de espaço social, que a tipologia socioespacial revela conjuntos de posições, formas da ocupação do espaço urbano, assim como também as territorialidades dessas posições refletem a busca do que se dispõe na geografia da cidade. Disso se poderiam ressaltar quatro atributos socioespaciais importantes da cidade: (1) a própria cidade, que significa mercado, oportunidades econômicas e consumo de serviços e mercadorias, garantias sociopolíticas; (2) a centralização, que significaria o conjunto dos benefícios da cidade reunidos em lugar central; (3) a localização e o acesso, ou seja, a facilidade de se chegar a um lugar central; e (4) a distinção da posição ocupada, que tem a ver com a diferença socioespacial definida pela

9 Ermínia Maricato busca nas ideias explanadas por Henri Lefebvre em "O Direito à Cidade" (1968) o reforço dessa ideia. Para nós, soa como concretude do espaço social urbano de nossas cidades e revela que é a própria ocupação da cidade, nos espaços de carência e precariedade (em periferia geográfica ou não), que o urbano vai se estendendo, clamando pela urbanização. 
concentração materializada no espaço dos valores de um grupo social.

Dessa forma, a ocupação da cidade que resulta em áreas irregulares ficaria nesse contexto recolocada. Quer dizer, não se trata apenas de falta de moradia, mas do significado que ela proporciona. No mapa (Figura 1), se vê que tais áreas não estão distribuídas uniformemente: (a) há grande concentração delas no extrato socioespacial médio; (b) as áreas localizadas nos extratos operário e popular estão majoritariamente próximas a esta última; (c) as que se localizam junto ao extrato superior são reduzidas, de menor extensão e estão bastante dispersas. No argumento de que elas se constituem como territórios, estariam marcando uma posição nesse espaço, como estratégia de seus protagonistas em busca daqueles atributos socioespaciais.

Tanto essas áreas se constituem em territórios, como a própria cidade, enquanto expressão de um ator ${ }^{\mathbf{1 0}}$ - o poder político instituído - se faz em território. $\mathrm{O}$ território tem a ver com a ação, que pode ser dos indivíduos, que deriva de uma "sutil 'alquimia' entre o pessoal e o coletivo" (TIZON, 1996, p. 21), como pode ser de uma instituição, por sua capacidade de poder e influência. Quer dizer, estão em jogo lógicas territoriais distintas, a dos atores da ocupação irregular e a dos atores do ordenamento do espaço urbano. Os espaços regulados da cidade, como o zoneamento e as unidades espaciais do Plano Diretor do Desenvolvimento Urbano e Ambiental (1999), se constituem com o objetivo principal "de estabelecer estratégias diferenciadas de regulação e controle do uso do solo" (HEIDRICH; HEIDRICH, 2010), segundo as características urbanas de cada uma delas. Por se fundar no princípio de controle sobre áreas, principalmente sobre o uso do solo urbano, é de sentido essencialmente territorial. Parte de um real e estabelece um ideal que se conjuga no equilíbrio de poderes aceitos que considera fundamentalmente visão técnica e formal.

Esse reconhecimento revela lógicas antagônicas, pois uma delas não está no plano, não é concebida no ordenamento territorial da cidade. É o que buscamos demonstrar a seguir com a sobreposição das ocupações irregulares às diferentes macrozonas do Plano Diretor do Desenvolvimento Urbano Ambiental (1999), de Porto Alegre (Figura 2).

Boa parte da área dos setores médios, como se viu anteriormente, constitui-se na macrozona Cidade de Transição e coincide com o de morros (da Polícia, Santana, Santa Tereza, Teresópolis) que separa a do Norte, de ocupação urbana intensiva, do Sul, de ocupação urbana rarefeita ${ }^{11}$. É área de interesse ambiental em função da presença das chamadas áreas verdes e de maior declive. Pois é justo esse espaço

10 “o ator não é simples agente. (...) É por vezes uma realidade mais ampla, um 'actante', no sentido genérico do termo. A palavra 'actante' designa uma instância, uma entidade identificável: indivíduo, mas também coletividade, organização, etc., um operador genérico dotado de uma capacidade de agir. (...) $\mathrm{O}$ ator realiza tudo consciente e deliberadamente. O agente é qualquer tipo de homem ou de mulher ordinários, sem qualidades específicas”. DI MÉO; BULÉON (2007, p. 29),

11 Plano Diretor de Desenvolvimento Urbano e Ambiental (1999). 
Figura 2: Áreas de ocupação irregular conforme o período da formação e Macrozonas do Plano Diretor de Desenvolvimento Urbano Ambiental de Porto Alegre.

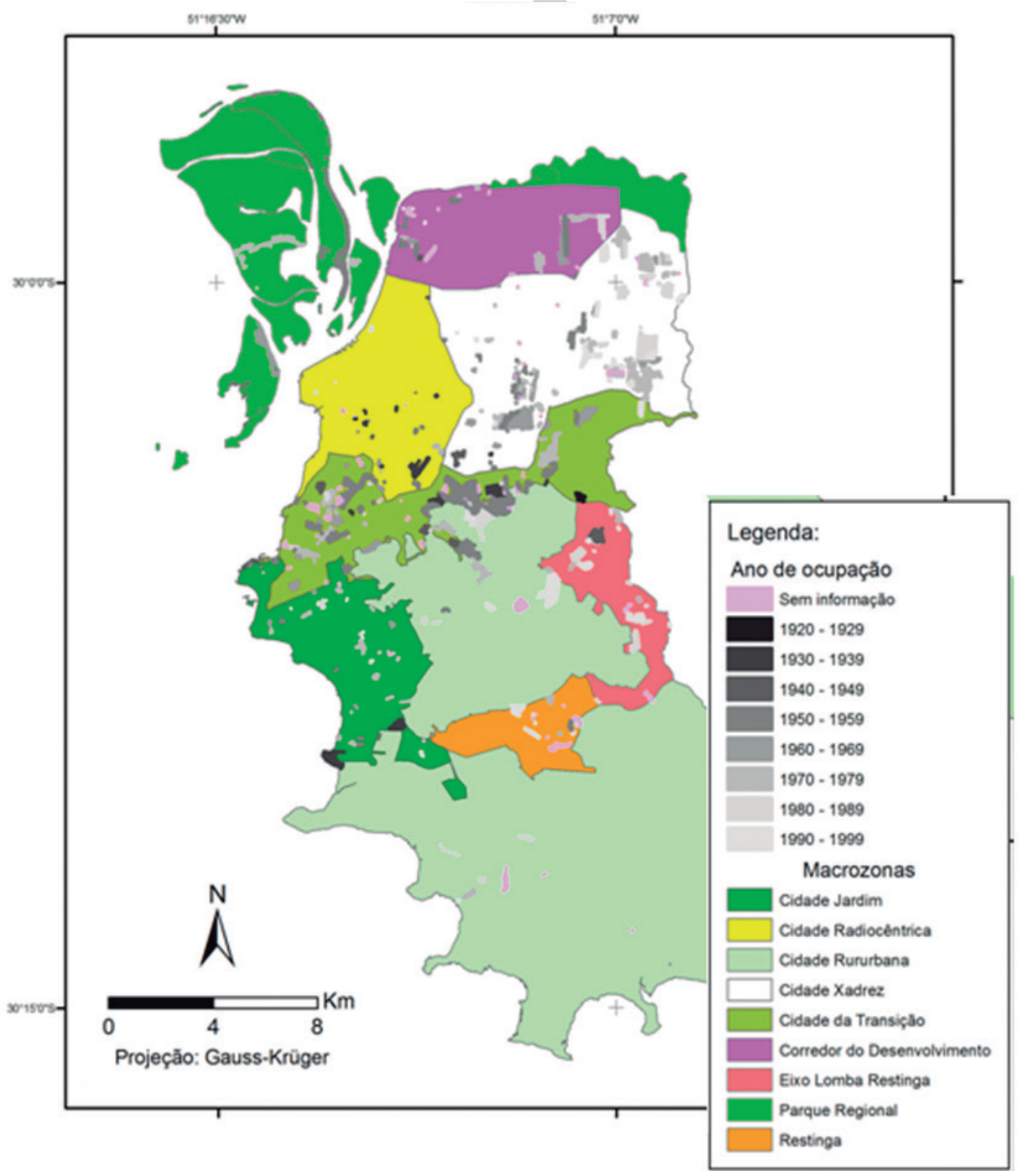

Fonte: DEMHAB e SPM.

Elaboração: Rodrigo Costa de Aguiar 
que combina a ocorrência de terrenos em declive em proximidade ao adensamento urbano que possui elevada concentração das áreas de ocupação irregular.

A Cidade Radiocêntrica compreende a área de povoamento mais antigo da cidade. É assim definida pelo seu traçado viário, que compreende vias radiais e perimetrais ao redor do centro. As ocupações irregulares no Centro Histórico e em alguns bairros adjacentes aparecem com muito menor intensidade e a sua formação predominante ocorre entre as décadas de 1920 e 1940, também as de registro mais antigo.

A macrozona Parque Regional abrange o Parque Saint Hilaire e as Ilhas do Delta do Rio Jacuí, e compreende as Áreas de Proteção Permanente. Nessa, a ocupação do espaço para moradia ocorre tanto a ocupação irregular em moradias populares como de classes mais abastadas. E, por haver interesse do capital imobiliário, estabelecem-se conflitos pelo uso do solo (classes médias e altas versus ocupações de classes pauperizadas).

No Corredor de Desenvolvimento, área considerada estratégica para a cidade, encontram-se as indústrias que ainda permaneceram na cidade, dado o processo de desindustrialização do núcleo metropolitano. Ela também possui comércios atacadistas, revenda de máquinas e implementos agrícolas e o complexo de abastecimento CEASA. A presença de duas grandes rodovias são fatores relevantes para a configuração desse espaço: a BR-116 e mais especialmente a BR-290, que lhe faz contorno pelo oeste e norte. As ocupações irregulares ocorrem próximas a esses eixos viários na entrada da cidade, com grande intensidade no bairro Farrapos a oeste e Sarandi a leste. Algumas poucas são mais antigas, da década de 1950, mas a maior parte são formadas nas últimas décadas do período analisado.

No Eixo Lomba-Restinga, macrozona caracterizada por ocupações populares, também são encontradas essas formas de apropriação. Nessa região, porém, a moradia em área irregular não destoa tanto em termos socioeconômicos e paisagísticos do contexto em que se localizam. Agregam-se ao periférico, à carência de recursos, serviços e infraestrutura.

Os bairros Tristeza, Vila Assunção, Ipanema, Serraria, Guarujá e Cavalhada, em conjunto, compõem a Cidade Jardim. Nessa macrozona, conforma-se a ocupação urbana associada à intensa arborização. Nos bairros Tristeza, Vila Assunção e Ipanema, pertencentes ao tipo socioespacial superior, encontra-se concentração de moradias de elevado padrão. Também há forte expansão e já se nota elevada concentração dos condomínios horizontais fechados (AGUIAR; HEIDRICH; UEDA, 2008). O contato de casas e condomínios horizontais de elite com as zonas pobres e de ocupação irregular produzem autênticas fraturas socioespaciais ${ }^{12}$.

12 Designação utilizada por nós para identificar uma variação da segregação espacial, aquela que se dá em proximidade e vizinhança, oportunizada pelo uso de tecnologias e artefatos de separação como os muros dos condomínios horizontais fechados (HEIDRICH, 2007; 2011). 
A área denominada Cidade Xadrez se caracteriza pela presença de alguns núcleos de centralidade secundária e pela urbanização altamente densificada. É região de elevada incorporação imobiliária e de produção de novas centralidades (SANFELICE, 2009). Nessa macrozona, as ocupações são encontradas em grande número, e acompanharam o desenvolvimento e a expansão urbana. $\mathrm{O}$ período em que passam a ocorrer é mais recente, posteriormente aos anos 1950 e com mais intensidade nas décadas mais recentes (posteriormente a 1980).

Em síntese, pode-se ver que as ocupações mais antigas estão próximas das áreas centrais, ao passo que as mais jovens estão mais distantes. Vê-se que a formação das vilas na cidade de Porto Alegre acompanharam o crescimento e a expansão urbana da cidade. Todavia, junto à Cidade de Transição - que envolve a cadeia de morros -, mesclam-se ocupações recentes e mais antigas. Assim, certamente esse meio geográfico, que faz as vezes de uma periferia, com maior dificuldade de acesso, é um fator interveniente. $\mathrm{Na}$ Cidade Jardim, cuja expansão urbana foi mais recente - sobretudo a partir da construção de condomínios horizontais - a formação de vilas foi também mais recente. No geral, quanto mais distante das áreas centrais, mais recentes são as ocupações, o que se evidencia também nas macrozonas Eixo Lomba-Restinga e Restinga. À medida que novas áreas são incorporadas ao mercado imobiliário, os terrenos em reserva - o solo sem destinação - vão se exaurindo as possibilidades de ocupação dos vazios mais próximos de centralidades. A busca pela compreensão da territorialidade dessas unidades irregulares de ocupação levou a um estudo baseado em levantamento de campo em cinco vilas irregulares em Porto Alegre, distribuídas espacialmente na malha urbana de Porto Alegre. $\mathrm{O}$ levantamento de campo considerou as vilas irregulares Icaraí II, Chocolatão, Areia, Minuano e Invasão, e contou também com entrevistas não-diretivas aos moradores.

\section{ESPAÇOS VIVIDOS DA OCUPAÇÃO}

No enfoque geográfico, paisagem e território se mesclam na constituição do espaço urbano. $\mathrm{O}$ território se sobrepõe a ela pelas práticas socioespaciais. E essas ações, com suas intencionalidades, revelam a tensão entre ocupação irregular e conformação legal, que disputam a constituição do espaço social, por suas posições. Elas se mesclam ao processo de constituição do urbano, embora não sejam áreas urbanizadas em seu início, pois geralmente se fazem a partir dos chamados vazios. Tais vazios são em maior parte terrenos de instituições públicas municipais, estaduais ou federais, alguns em situação de litígio e poucos de propriedade $\operatorname{particular}^{13}$. São

13 Como pudemos verificar em nossa pesquisa, é de absoluta predominância a ocupação de terrenos públicos e imóveis de cooperativas e companhias e cooperativas habitacionais. A ocupação de terrenos privados tem registro, mas, em minoria, e em geral nas áreas mais afastadas do urbano denso e das centralidades. Ver AGUIAR; HEIDRICH (2011). 
áreas com falta ou precariedade de equipamentos urbanos ou benfeitorias, mas, de forma predominante, se localizam nas proximidades de tais recursos. É bastante comum, antes da ocupação, não serem portadoras de meios de consumo coletivo ${ }^{14}$. Como se depreende da memória de seus protagonistas, essas áreas antes de serem ocupadas possuíam o perfil de áreas relegadas:

(...) Aí ele falou para o meu marido, que ele é primo do meu marido. Aí ele disse assim "a gente vai invadir aquele pedaço do lado de lá". Porque isso aqui era uns cômoros de areia, que eles tiravam do valão, tiravam do Guaíba e atiram pra cá, então tinha uns lugar que eram uns buraco, tinha outros que era areia até lá em cima ... aí a gente foi... aí a gente veio. Aí do lado a gente alugava duas peça, que era eu, meu marido, meu filho mais velho, que tá na faculdade hoje e essa que mora aqui. Aí então a gente... né, vamo se reunir com o pessoal e aí foi vindo, foi vindo, foi um, foi vindo outro, e a gente foi pegando pedaço pra um, pedaço pra outro... aí foi indo (moradora da Vila Icaraí II).

Após a ocupação, essas áreas guardam as características de espaços próprios por seus aspectos diferenciados no tecido urbano, mas, já antes disso, são cantos e nesgas dos lotes urbanos, muitas vezes nas condições que oferecem maior risco à moradia, como as áreas inundáveis juntos aos cursos d'água ou encostas mais íngremes (Figuras 3 e 4).

A constituição desses espaços possui dinâmica similar às que formam as periferias, em função da carência e da precariedade dos atributos da urbanização. Parece ser uma característica bastante peculiar deste processo, misturar as feições da constituição do espaço produzido às histórias particulares de luta por uma moradia. Trata-se de uma necessidade dupla, pois o residir implica em ter o lar e a localização na cidade. Para Nola Gamalho (2010, p. 132):

Se para a parcela da população que participa do consumo da cidade enquanto mercadoria, a habitação adquire status de desejo vinculado a amenidades, como localização, incidência solar e equipamentos como elevador, piscina, entre outros, para o segmento desprovido da condição de consumidor o desejo é fundido à necessidade, e o ato de habitar está para além do consumo, é o progresso social.

Com a permanência nesses locais, aos poucos as comunidades logram conquista de melhorias. $\mathrm{O}$ abastecimento de água, muitas vezes uma torneira para uma vila inteira e, nos casos mais antigos, diretamente nas moradias, é o serviço mais solicitado. A energia elétrica muitas vezes é capturada diretamente da rede, sem registro. Calçamento e esgotamento sanitário também é comum faltarem.

14 Os meios de consumo coletivos possuem três características principais: (a) eles não são destinados ao consumo individual, portanto, seu valor de uso é coletivo (como uma praça, o transporte coletivo); (b) há dificuldade de fazer sua introdução no setor das mercadorias, em função da lentidão de sua renovação, produzindo uma rentabilidade capitalista muito fraca; (c) eles não se combinam com produtos materiais separados, exteriores às atividades que o produziram (como edifícios escolares, hospitalares). (LOJKINE, 1981, p. 132-135). 
Figura 3: Vila Icaraí II, Arroio Icaraí.

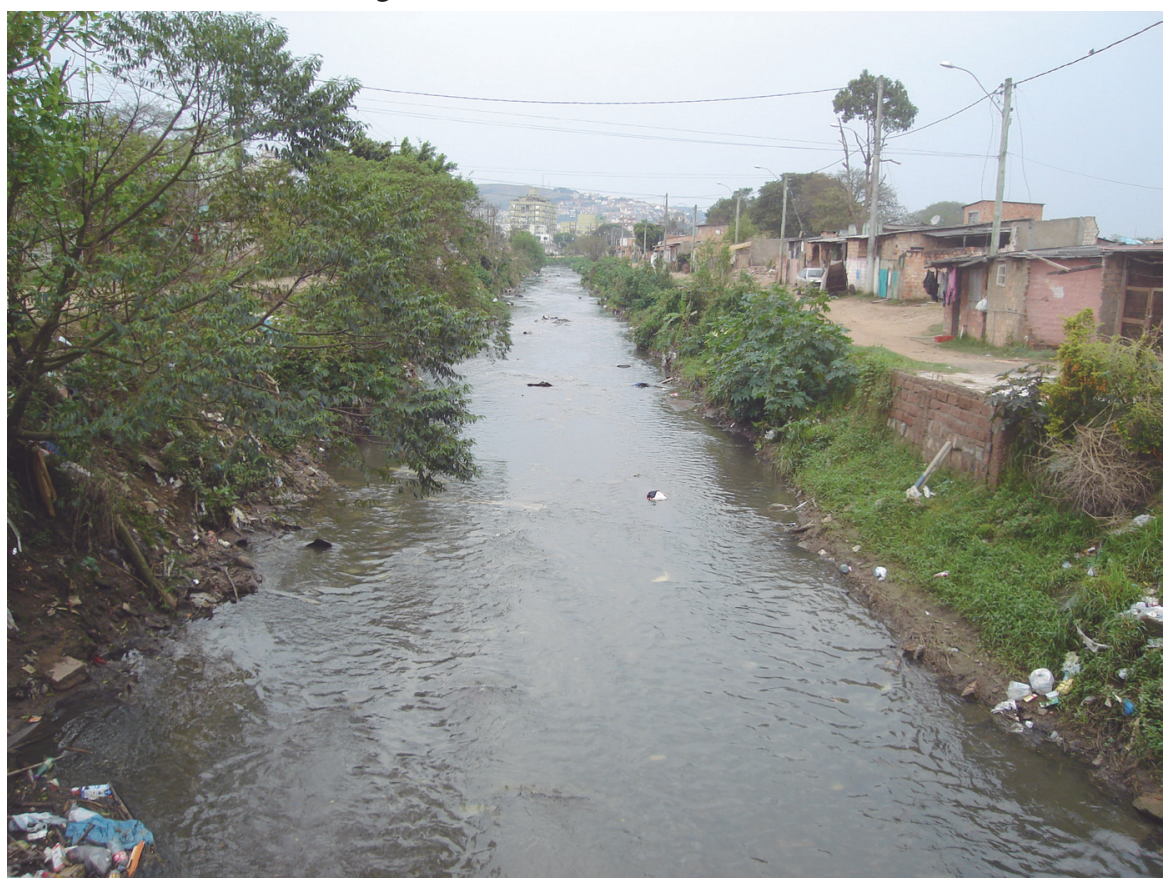

Foto: Amanda de Souza e Cristiano Teixeira, 2010.

Figura 4: Vila Icaraí II.

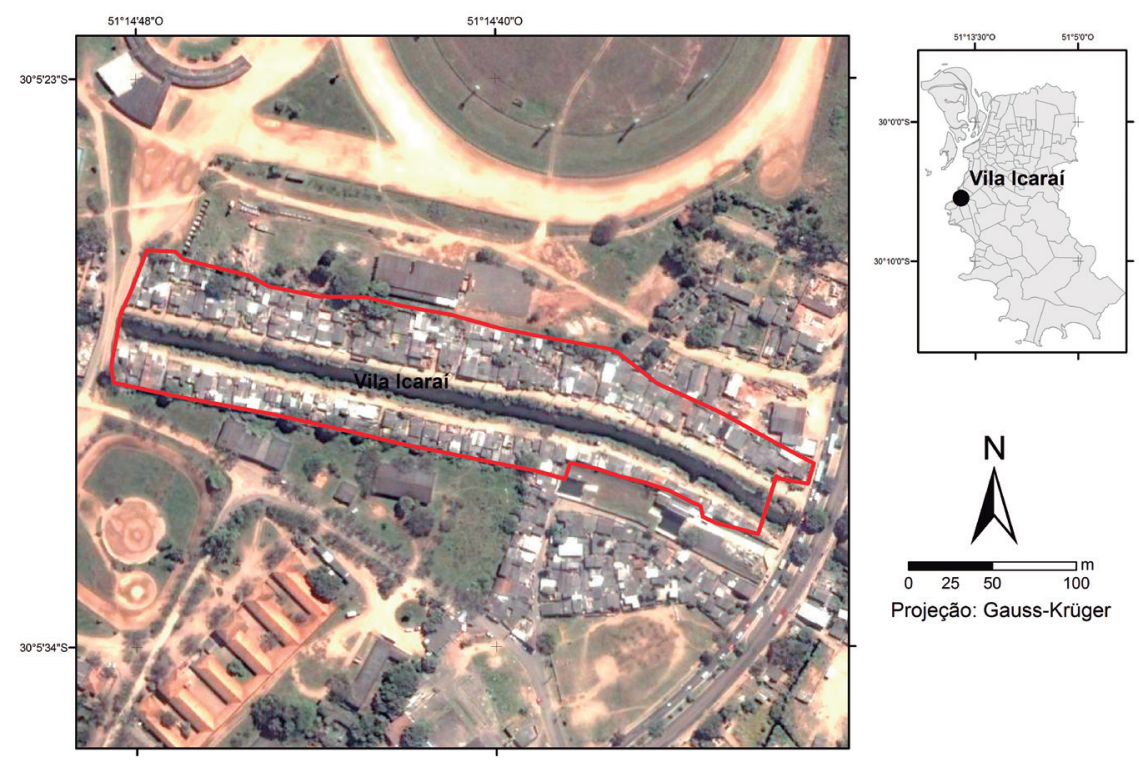

Fonte da imagem: Quickbird, DEMHAB, 2008.

Geoprocessamento: Rodrigo Costa de Aguiar. 
Porém, a escola para os filhos, o transporte público e o encontro de alternativas de trabalho que a localização proporciona, vão se somando ao histórico de conquistas e assim vai se fazendo o diálogo das comunidades ocupantes com a cidade. Isso produz um importante sentido: as áreas ainda não incorporadas plenamente à cidade vão ganhando a cidade em virtude de uma prática territorial. É o fato que enlaça e articula. Numa relação em que ao mesmo tempo há inserção e falta, como um movimento ininterrupto ${ }^{15}$.

É um aspecto muito nítido da relação da condição territorial, quando se tem uma marca de espaço singularizado, que faz relação com o contexto maior por intermédio do seu conjunto particular. Não é a comunidade em si, apenas, é todo um pedaço de cidade. E, como se trata disso, o território contém, além do fato em si, o sentimento de fazer parte, de pertencer e sentir-se vinculado. Considerando a relação dessas comunidades consigo mesmas e de seus territórios com a cidade, Ana Fontoura (2008, p. 381-382) explicita que se tem:
(...) de um lado, a construção de identidades que se manifestam através da existência de códigos e de histórias comuns que unem uns e fazem separar outros, criando-se fronteiras imaginárias intransponíveis que não aparecem nos mapas, mas existem no dia-a-dia, dificultando o diálogo e impedindo as ações; do outro lado, a relação com o poder público municipal, especialmente diante de uma proposta gerada numa rede de ação tecida entre Estado e agentes sociais excluídos.

Mesmo levando-se em conta que a constituição dessas ocupações possui um sentido comum, não significa que seus ocupantes expressem uma única compreensão sobre os problemas que lhes afligem. Em muitos sentidos, essas ocupações podem ser vistas como uma comunidade - de vizinhança, territorial -, mas constituem um corpo social complexo, que possui diferenças e certamente divergências. Elas apresentam-se com aspecto unificado por causa de sua expressão territorial, pois esta é a condição que identifica a que se pertence. Para Di Méo e Buleón (2007, p. 118), "o ideal é uma condição necessária para a formação das realidades materiais e da reprodução das relações que engendram” e, quando vinculadas ao território, as representações consubstanciam materialidade e imaterialidade.

Territórios são vistos e percebidos por seus conteúdos simbólicos (RAFFESTIN, 1988), por aquilo que significam nas duas direções, de quem participa dele e de quem está fora. Evidentemente que o mapa é sua melhor representação, mas poderíamos dizer que nem todos são mapas geográficos, alguns são feitos de memórias, outros de literatura, discursos etc. $\mathrm{O}$ que se retrata em qualquer uma dessas formas de representar o espaço tem a ver com a preocupação de quem comunica e, por isso,

15 Em Porto Alegre, considerando-se os dados do Censo Demográfico de 2010, cerca de $11 \%$ dos domicílios (56.024) localizavam-se em favelas, os chamados aglomerados subnormais. Cf. IBGE, Censo Demográfico 2010, resultados do universo, aglomerados subnormais. Disponivel em: $<\mathrm{http}: / /$ cidades.ibge.gov.br>. Acesso em: 10 de out. de 2014. 
retrata uma territorialidade específica. Assim como se nota facilmente no argumento sobre as nacionalidades, que se apoia nos atributos geográficos, históricos e culturais de um país, também os contornos e os conteúdos das demais territorialidades, como a das vilas, são construções desse tipo.

Nas áreas ocupadas, a ligação de uns com todos, isto é, a coesão em torno da territorialidade, parece se dar pela associação dos elementos em junção, extraídos do compartilhamento do espaço-tempo. Viver numa mesma geografia e vivenciar seus fatos contribui para a elaboração de referentes da vida, para a identidade do grupo. Por mais que haja qualquer diferença de opinião, rusga ou desconforto entre vizinhos, a referência que contribui para a visão de cada um no contexto origina-se na mesma realidade socioterritorial. Compartilham uma reivindicação bastante comum: ter o direito de se manterem no lugar, de estar na cidade. Quando indagados sobre o lugar, em geral se reportam assim: "aquilo ali não era de ninguém” (morador da Vila Chocolatão), ou "era lugar abandonado, a gente é que deu o jeito nisso" (moradora da Vila Icaraí II). Também é comum a percepção de que os poderes públicos possuem uma dívida com eles, um compromisso com o problema que vivenciam, de lhes faltarem serviços e equipamentos urbanos. Compreendem isso a partir da comparação com os bairros bem atendidos.

As modalidades da chegada ao lugar são muito semelhantes, quase sempre iniciadas por poucas famílias. Com certa rapidez, elas somam-se aos que aguardavam um pouco de certeza, conhecidos e parentes. Mas o espaço não se completa imediatamente, já que cresce a ocupação por subdivisão dos primeiros lotes.

A ocupação dá, a quem tem a posse, certo "direito" sobre o lugar. Uma habitação, mesmo que sem registro formal na cidade, tem seu valor de uso e situa-se numa posição em relação aos benefícios que o urbano contém. Pode-se ver que as casas levantadas podem ser trocadas por pequenas quantias, que muitas vezes são estabelecidas com o parâmetro da necessidade de quem se muda. Quando decorrido algum tempo, e a localização é favorecida por algum incremento da cidade, pode-se auferir um valor. Esse aspecto se entrelaça com o original, à maneira de um conflito de estratégias: a de ganhar a cidade e a de servir-se do recurso da ocupação como estratégia de reprodução social. Para Bonduki e Rolnik (1979, p. 129), a ocupação de terrenos distantes, a autoconstrução e a contínua repetição contribuem para manutenção da baixa remuneração dos trabalhadores:

(...) ao produzir sozinho sua casa, o trabalhador cria um valor de uso, apropriado totalmente por ele, e que é, potencialmente uma mercadoria, pois pode ser comercializado a qualquer momento. (...) Se, numa primeira instância, a habitação resultante dessa operação é produzida como valor de uso, passa a ter valor de troca quando é mercantilizada, através de venda ou locação, muito frequentes.

Se, por um lado, a autoconstrução tem sua origem nos baixos salários, ao generalizarse institucionaliza essa baixa de salários. Há, portanto, um sobretrabalho implícito ao processo, mas este não se encontra no trabalho de construção da habitação propriamente dito e sim na diminuição da magnitude do "trabalho necessário" 
na jornada cotidiana de trabalho, possibilitada pela eliminação do gasto mensal equivalente ao aluguel.

Mesmo que isso deva ser compreendido como sistêmico, é significativo que muitos são trabalhadores do circuito inferior da economia, não assalariados. Desse modo, usufruir do rendimento auferido pela venda da sua habitação (benfeitoria e localização), em muitos casos, vai se constituindo em prática de reprodução social. Essa estratégia é utilizada por alguns moradores de reassentamentos ou áreas reurbanizadas, quando repassam a moradia conquistada por troca financeira, retornando à dinâmica de ocupação, que pode ser em outro local ou até na mesma área, seguida das práticas da autoconstrução e reivindicação por melhorias urbanas. Evidenciou-se essa dinâmica na Vila Areia, vila irregular que está integrada a um projeto de reurbanização em realização no bairro Farrapos ${ }^{16}$. Segundo relatos dos moradores mais antigos, essa prática se dá há muitos anos, o que dificulta que aqueles que estão há mais tempo no local recebam uma nova casa, pois a (re)ocupação do local é constante, isso fica evidente em uma frase de um morador: "a Vila Areia nunca acaba!". O fato de a vila ser constantemente ocupada faz com que coexistam moradores bastante antigos, de mais de vinte anos, e moradores muito recentes, de menos de um ano. A vila é composta de barracos e sofre constantemente processos de remoção e nova ocupação. A Figura 6 mostra como o espaço da vila está vazio, enquanto a Figura 5 apresenta a vila reocupada. Nesse caso, evidencia-se que a fiscalização não é eficiente, permitindo que novas ocupações se estabeleçam a partir da instalação de novos barracos, tornando inviável a retirada dessas ocupações quando já possuem famílias morando.A territorialidade, dessa forma, não permanece, mudam as pessoas e as relações bastante rapidamente (TEIXEIRA; SOUZA; HEIDRICH, 2011). Ela é bastante instável, a memória coletiva é fragmentária, já que uns saem e outros chegam com muita rapidez. Assim, as mudanças não envolvem apenas a paisagem, mas também os compartilhamentos e, evidentemente, os sentidos das experiências.

A coesão dessas comunidades, por serem pequenas, nos leva a pensar que se mantenha forte, resultante de uma vida preenchida de significados comuns. Mas ela é atravessada por diferenças pertinentes às sociedades complexas, considerando-se a multiplicidade de experiências, como, por exemplo, suas opções religiosas, seus

16 Esse bairro, com muitas áreas de ocupação irregulares (ver figura 2), tem sido objeto de importante programa de reforma urbana. O Programa Integrado Entrada da Cidade, conforme divulgado pela Prefeitura Municipal de Porto Alegre, visa ao desenvolvimento urbano, socioeconômico e ambiental da região e conta com investimento de R 140 milhões. As ações, voltadas para a construção de habitações no próprio local de ocupação, implantação de sistema viário e saneamento, atendendo 3.775 famílias com 3.061 novas casas e 714 lotes urbanizados. O programa conta com financiamento externo e recursos municipais. Já foram entregues 1629 Unidades Habitacionais. Restam aproximadamente seis vilas a sofrerem intervenção, que estão em análise pelo PIEC. Atualmente as vilas Areia e Tio Zeca estão em vias de realocação, por responsabilidade do Departamento Nacional de Infraestrutura de Transportes (DNIT), em função de ali estar projetada a alça de acesso da segunda travessia do Guaíba. 
Figura 5: Vila Areia. Área reocupada.

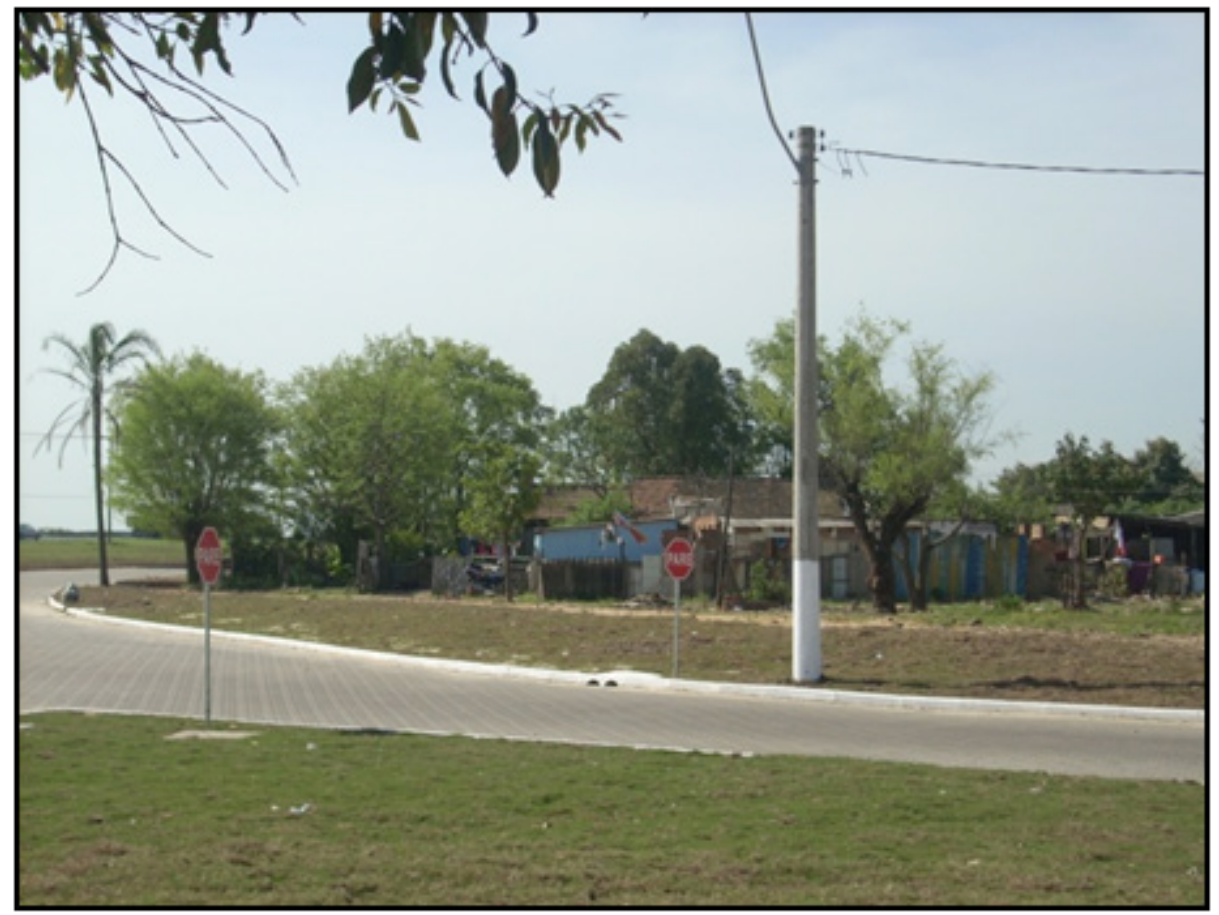

Foto: Amanda de Souza e Cristiano Teixeira, 2010.

Figura 6: Vila Areia em remoção. Ao centro, vê-se área reurbanizada e, abaixo, pavilhões de

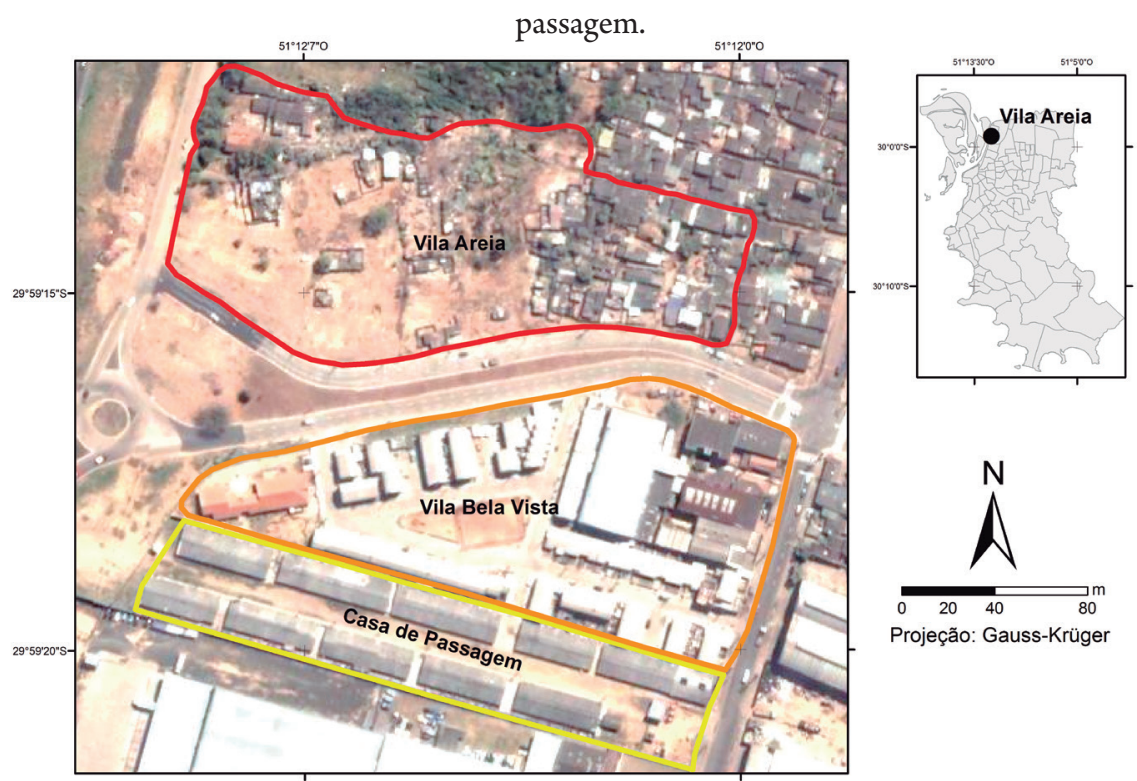

Fonte da imagem: Quickbird, DEMHAB, 2008.

Geoprocessamento: Rodrigo Costa de Aguiar. 
lugares de origem e alternativas de condução da vida que variam não apenas pelo encontro da oportunidade de trabalho, mas também pela sujeição às formas menos lícitas de obtenção de rendimento. Assim, tanto o sentido da aproximação como de certo afastamento estão presentes nas dinâmicas de formação desses pequenos territórios. Por isso, entendemos que o conjunto social dessas ocupações deve ser refletido (averiguado) como comunidades detentoras de reservatórios de sentidos, que não seriam únicos, mas plurais. O sentido, como compreendem Peter Berger e Thomas Luckmann (2004, p. 15-16), é:

(...) uma forma complexa de consciência [que] não existe em si, mas sempre possui um objeto de referência. Sentido é a consciência de que existe uma relação entre experiências. O inverso também é válido: o sentido de experiências - e (...) ações - será construído em primeiro lugar por especiais realizações "relacionais" da consciência. A experiência atual em dado momento pode ser relacionada com uma experiência já acontecida há pouco ou num passado remoto. Geralmente a experiência atual não é relacionada com uma única outra experiência, mas com um tipo de experiência, um esquema de experiência, uma máxima comportamental, uma legitimação moral, etc., derivados de muitas experiências e armazenados no conhecimento subjetivo ou tomados do acervo social do conhecimento.

Com isso, se compreende que as experiências aqui relatadas se associam à geografia do lugar ocupado e seu contexto na cidade; associam-se ao cotidiano, que envolve subemprego, estratégias de subsistência e a convivência contraditória entre a precariedade e a presença da urbanidade; e o próprio agir, que envolve principalmente a itinerância e a ocupação. Por isso, o que aproxima não é viver a mesma coisa, mas compartilhar uma espécie de confluência, como um repositório. Mesmo que o que se viva não diga respeito a todos, o que todos vivem conflui para a uma mesma referência, impregnada de fatos localizados.

Na Vila Icaraí II (Figuras 3 e 4), a ocupação foi iniciada nos primeiros anos da década 1990 por poucas famílias, que viram o lugar como um espaço sobrante, o uso vinha sendo feito para rejeito de caliça. Foi pelos protagonistas compreendido que ali poderiam instalar moradia, permanecendo na mesma região da cidade, sem a despesa dos aluguéis. A ação, com o tempo, foi seguida da chegada de um conhecido ou parente no espaço que foi aberto e, também, pela compra da casa de alguém. O lugar possui uma grande densidade de moradias, que aos poucos têm sido removidas ${ }^{17}$, mas nem todos se conhecem e compartilham da mesma memória

17 Durante o levantamento de campo, em 2009, permaneciam 108 domicílios no local. Parte dos moradores foram retirados do local, mediante a indenização no valor de $\mathrm{R} \$ 40.000,00$, e aqueles que optam pela moradia têm sido reassentados em vilas junto ao bairro Cristal, próximos do local, como as vilas Campos Velho e Nossa Senhora das Graças ou, mais distantes, na região sul da cidade, como a Vila Hípica. O reassentamento dos moradores da região é parte do Programa Integrado Socioambiental (PISA), que compreende ações de obras de proteção contra cheias, a construção de novas moradias e vias que contornarão a margem do arroio Cavalhada. Parte dos recursos do programa origina-se de medidas mitigatórias da implantação do Centro de compras Barra Shopping Sul. Cf. Prefeitura 
sobre como o lugar se formou. A atividade das pessoas é bastante variável nessa vila e nota-se que, em relação a outros espaços de maior vulnerabilidade social da cidade, um aspecto geral de melhor situação social, como a presença não desprezível do emprego formal e moradias bem equipadas com bens de consumo duráveis.

A Vila Chocolatão, já removida (Figuras 7 e 8), foi uma ocupação em área central da cidade, em local vizinho a prédios de instituições públicas, como Tribunal Regional Federal, Receita Federal, Instituto de Colonização e Reforma Agrária, Instituto Brasileiro de Geografia e Estatística, entre outros. As primeiras ocupações se fizeram em meados dos anos 1980, por pessoas vindas de diferentes locais da cidade e, muitas delas, moradores de rua. Os moradores que permaneciam no local previamente à remoção distribuíam-se entre 181 famílias e eram majoritariamente recicladores de resíduos sólidos, popularmente conhecidos por catadores. A distribuição dos barracos no lugar possuía um arranjo apertado, com ruelas pequenas que permitiam o tráfego de um carrinho de coleta por vez. Numa área mais central, a maneira de uma esplanada, algumas instalações de encontro, como um bar/armazém, dois brinquedos de praça para as crianças e um clube de mães - local das atividades sociais, recepção de doações e reuniões com as muitas instituições de assistência social ou organizações que ali desenvolviam algum apoio ou projeto ${ }^{18}$. Porém, tudo era muito precário. $\mathrm{O}$ que havia de infraestrutura melhor era um conjunto de quatro banheiros e tanques com torneira, já há bastante tempo com os dutos estourados, fazendo espalhar o esgotamento por baixo dos barracos. As ligações de energia elétrica, os chamados "gatos", realizadas pelos próprios moradores já haviam ocasionado diversos incêndios. Também era local em que se alteravam muito os moradores, apesar de permanecer um grupo antigo, que mantinha a memória do lugar.

A Vila Minuano é um espaço de ocupação bastante antigo e, pode-se dizer, estável, pois não há processo de intervenção em projeto. Trata-se de uma situação acomodada, mesmo que com nítida diferenciação da qualidade das construções. Junto ao córrego do Dique Sarandi, as moradias mais precárias estão em lugar mais agradável, por causa do espaço que permite a arborização e o uso do lugar para lazer (Figuras 9 e 10).Os moradores construíram à margem do córrego uma pequena praça arborizada, que, além de um refúgio nos dias de calor, é a materialização das relações humanas no espaço, revelando, por meio do uso, o sentimento de pertencimento

de Porto Alegre, Secretaria Municipal de Gestão, Projeto Integrado Socioambiental. Disponivel em: $<$ http://www2.portoalegre.rs.gov.br/smgae>. Acesso em: 10 de out. de 2014.

18 Dentre as inúmeras entidades que atuam na Vila, destacamos as seguintes: GAJUP - Grupo de Assessoria Justiça Popular, CARU - Coletivo de Apoio à Reforma Urbana, ambos da Universidade Federal do Rio Grande do Sul; projeto Pim Pim Piá - Primeira Infância Melhor, da Prefeitura Municipal de Porto Alegre; CAMP - ONG a serviço da empresa VONPAR; igrejas e grupos religiosos; CONTERRA - grupo contratado pela empreiteira de obras para executar o Projeto de Trabalho Técnico Social de reassentamento; Grupo de Apoio Social do Posto de Saúde Santa Marta; e a Rede para Sustentabilidade da Vila Chocolatão - rede municipal -, participam todas as secretarias da Prefeitura, algumas empresas como a Vonpar, representante da UNESCO e do Tribunal Regional Federal. 
Figura 7: Vila Chocolatão.

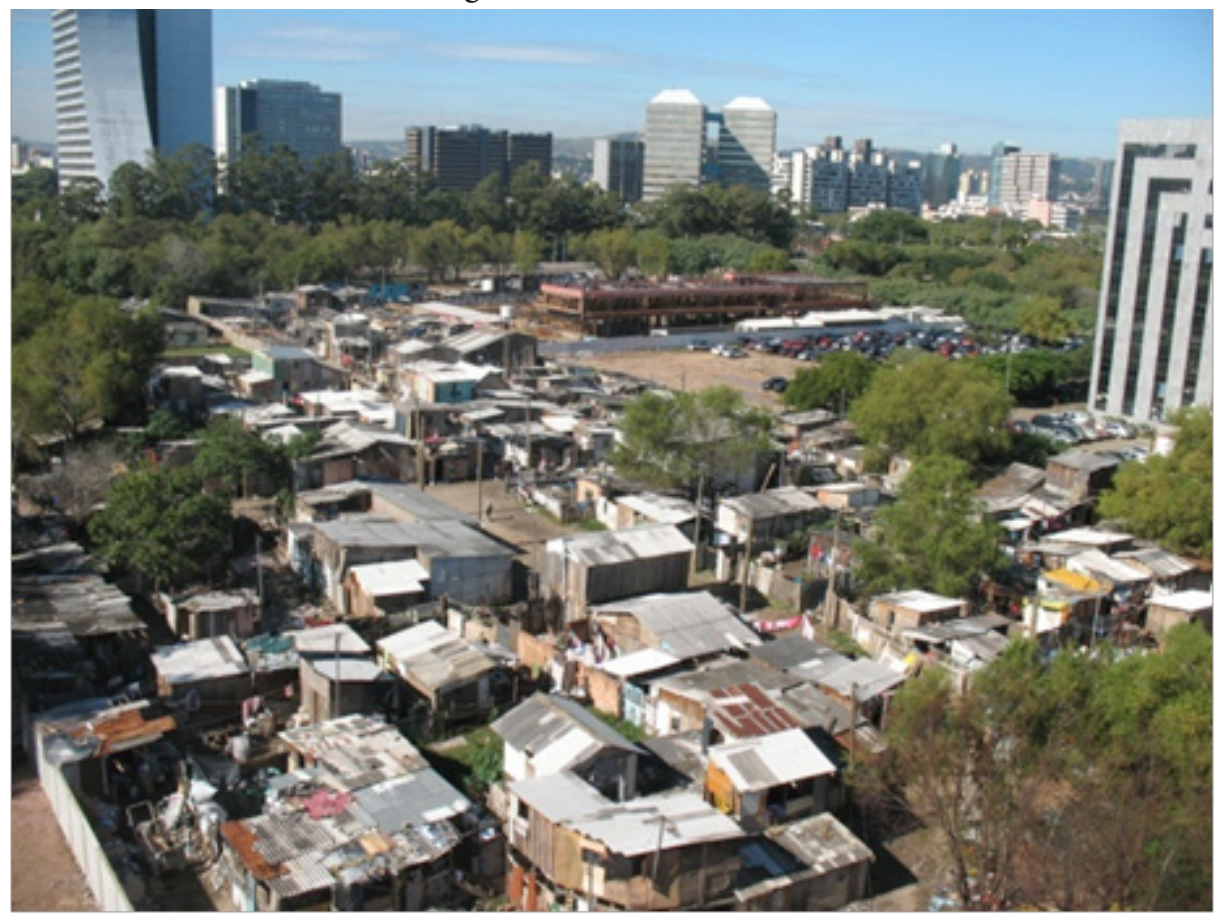

Foto: Miriam Claussen, 2010.

Figura 8: Vila Chocolatão.
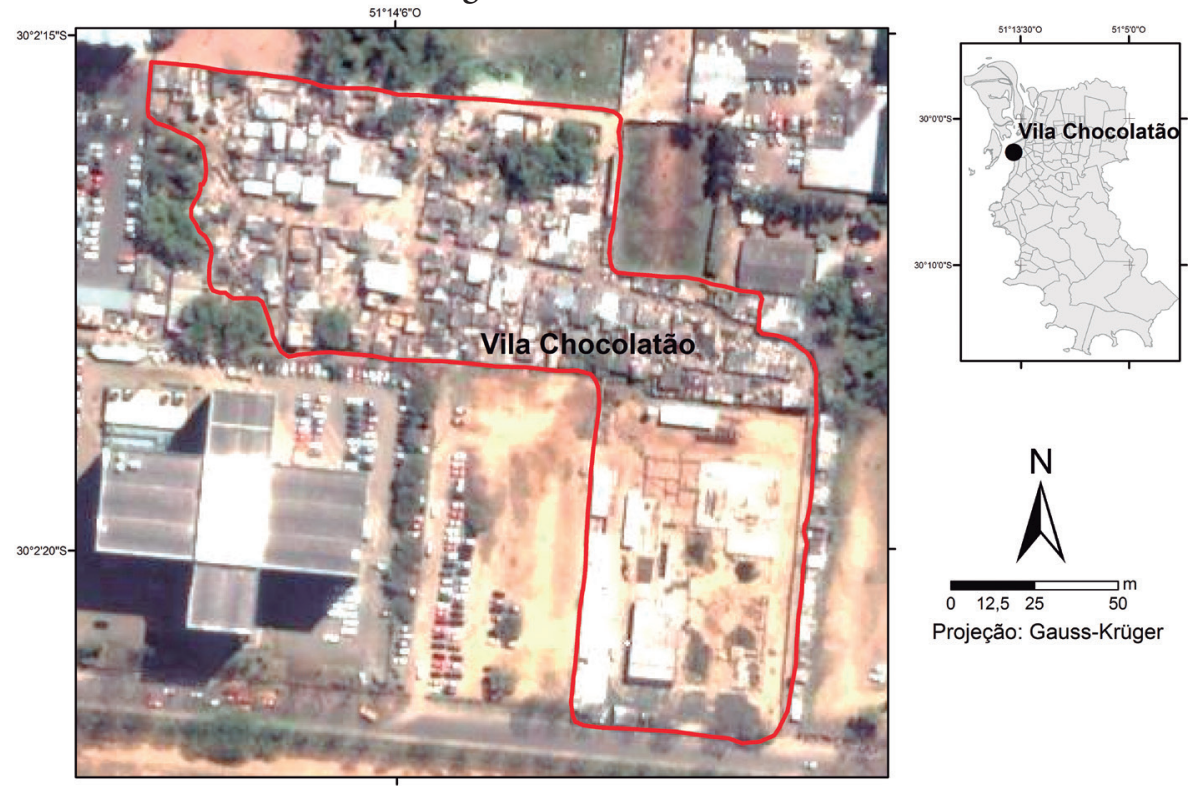

Projeção: Gauss-Krüger

Fonte da imagem: Quickbird, DEMHAB, 2008.

Geoprocessamento: Rodrigo de Aguiar. 
Figura 9: Vila Minuano. Recanto construído pelos moradores junto ao córrego do Dique Sarandi.

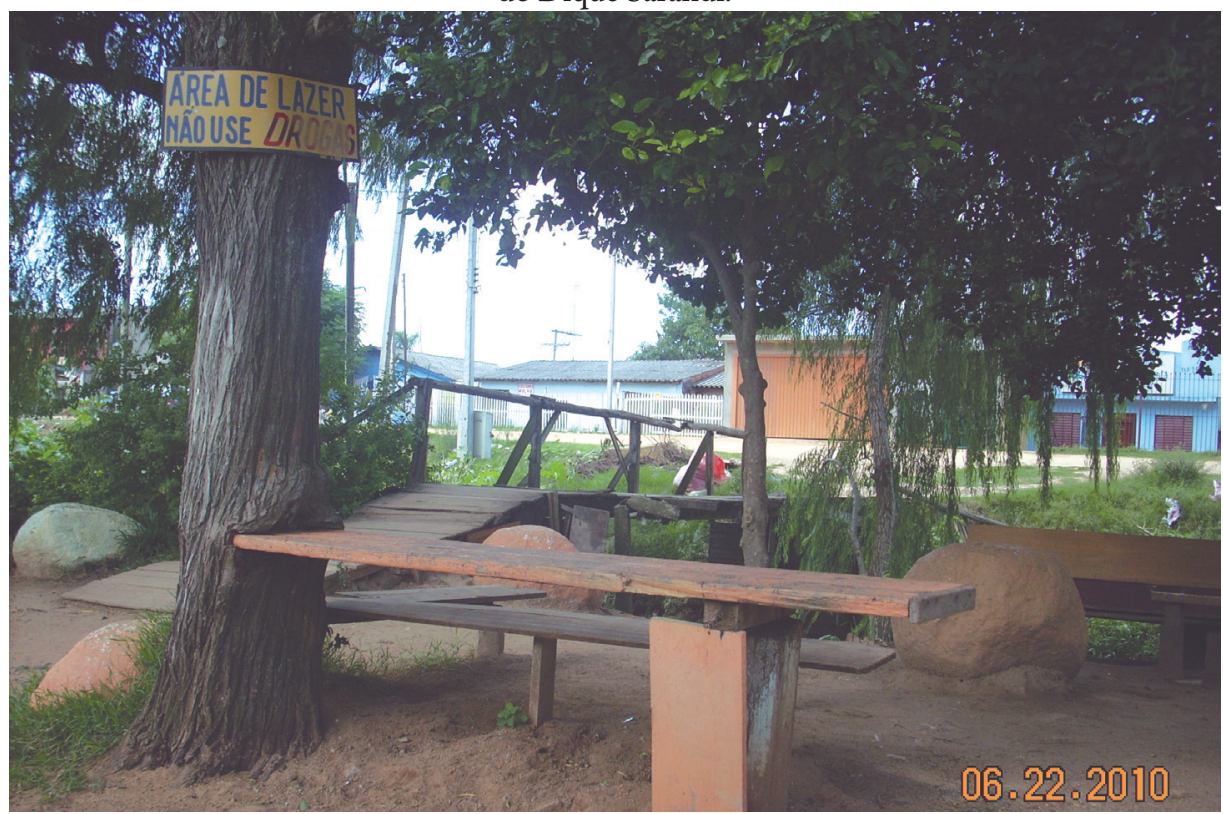

Foto: Amanda Souza e Cristiano Teixeira, 2010.

Figura 10: Vila Minuano.
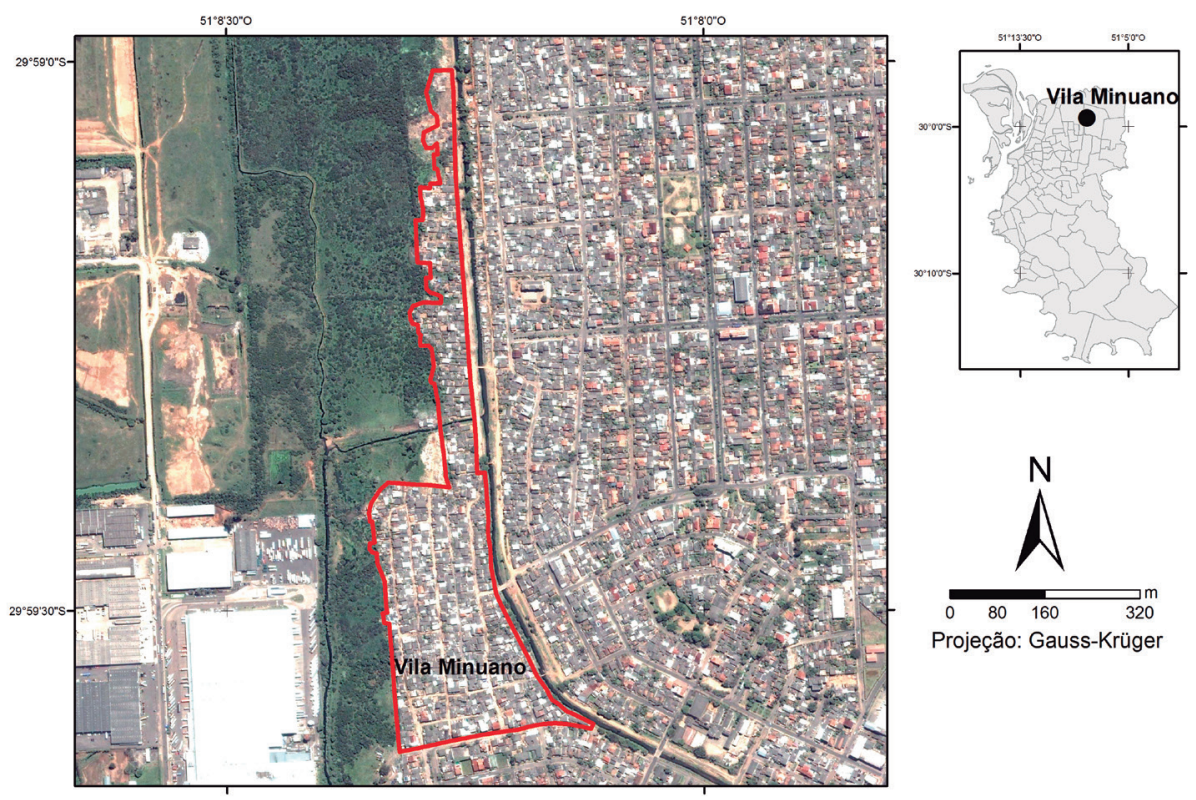

Fonte da imagem: Quickbird, DEMHAB, 2008.

Geoprocessamento: Rodrigo de Aguiar 
ao lugar que construíram como alternativa para reprodução da vida. Nota-se o zelo pelo aspecto do ambiente e pelas recomendações expostas nas placas, como: área de lazer, não use drogas.

$\mathrm{Na}$ ocupação conhecida por Invasão (da Restinga), o processo de reassentamento, iniciado em 2011, contribui para fragilizar a relação dos moradores com o seu lugar. A consciência de que o futuro, o "lar", não será construído ali, é percebida pelos sujeitos como um motivador para não melhorarem as suas casas e infraestrutura da vila (Figuras 11 e 12), já que não estarão mais naquela área em alguns meses. Além disso, a origem dos moradores e o uso da ocupação revelam duas territorialidades distintas na mesma área. Esses contrastes de características, além de terem o tempo de ocupação como variável, são expressos também pelo tipo de renda dos moradores e pelas relações de vizinhança.

Na parte antiga (onde surgiu a ocupação), nota-se que, além de uma maior transitoriedade, há relação conflitante entre os vizinhos na disputa pelo atendimento básico de suas necessidades, não pouco negligenciado pelas instituições assistenciais, por causa da condição irregular da ocupação. Já na parte nova (para onde a vila se expandiu), os moradores se sentem mais à vontade de estar na rua e nos pátios de suas casas. $\mathrm{O}$ uso do espaço para moradia é menos denso e a relação entre vizinhos encontra-se bem ancorada por relações de solidariedade. $\mathrm{O}$ contraste entre eles vai além do período da ocupação, são territorialidades muito distintas reveladas a partir das identidades, representações, uso do solo e relações entre as vizinhanças de cada território.

No território que inicia a ocupação, há uma maior carência de infraestrutura, assim como falta de segurança e tráfico de entorpecentes. A relação entre os moradores é influenciada a partir das estratégias ilícitas de obtenção de renda existente. Nota-se que as pessoas sentem constrangimento e dificuldade em responder o questionário, como se vê nos gestos, como cobrir a boca com a mão durante uma conversa que chega ao tema, "escondendo" o que diziam. O gesto defensivo, de quem de alguma maneira quer proteger-se, é gesto simbólico, de quem é oprimido e vigiado, nos revelou a complexidade das relações de micropoder que permeiam a vida cotidiana no lugar.

A paisagem do território da ocupação mais recente revela um clima de tranquilidade e segurança. A infraestrutura (rede de esgoto e energia) foi instalada pelos próprios moradores em "mutirões". A partir das relações com espaço, possibilita a representação das individualidades, como por exemplo: um pátio que se torna, para alguns, espaço que simboliza liberdade, uma liberdade que opõe a vida com características do campo, ainda presentes na Restinga, ao caos urbano: "eu gosto de morar aqui (no território mais novo da Invasão), no meio do mato, tranquilidade (...) tu acorda com os passarinhos (...) porque é ruim tu acordar no meio de buzinas e gritaria" ${ }^{19}$. 
Figura 11: Invasão da Restinga.

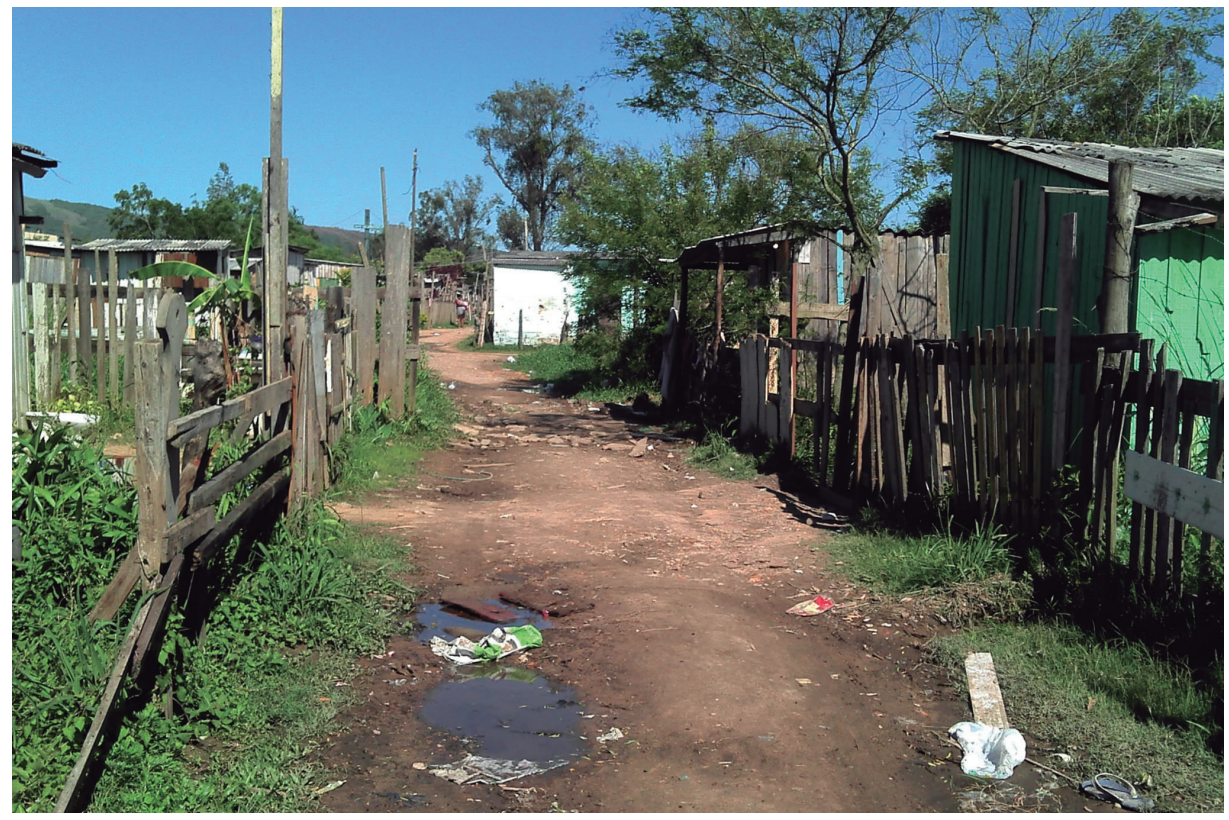

Foto: Felipe Dal Piva e Marília Rathmann, 2011.

Figura 12: Invasão da Restinga.
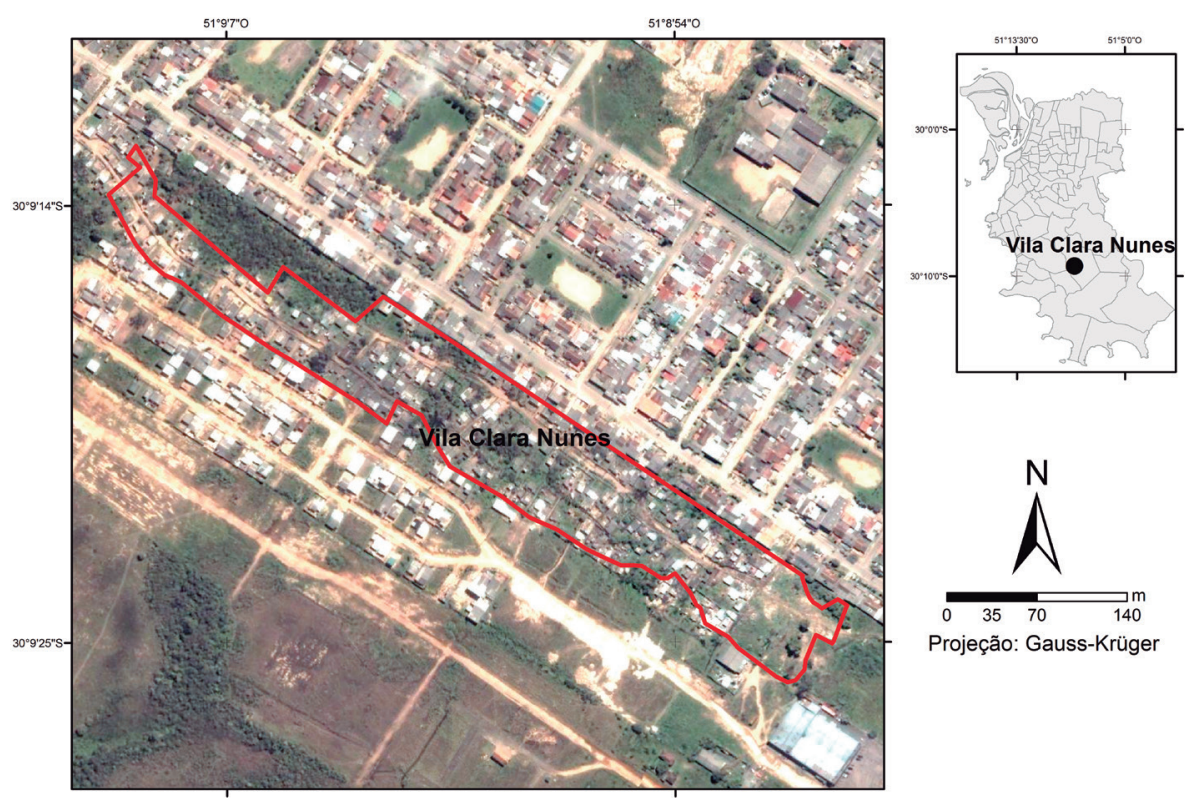

Fonte da imagem: Quickbird, DEMHAB, 2008.

Geoprocessamento: Rodrigo de Aguiar. 
Essas vilas possuem um duplo aspecto buscado por suas comunidades: centralidade e urbanidade. Estão localizadas em regiões da cidade com acessibilidade a serviços, escolas, fonte de geração de renda. Elas guardam, por sua localização, essa possibilidade de acesso aos atributos da cidade. Todas elas estão em processo de regularização, remoção ou reassentamento.

A Vila Areia, como já ressaltado, é objeto de reassentamento e vinha sempre se caracterizando por uma repetida mudança de seus ocupantes. Dois aspectos foram comentados, e que nos parecerem muito associados ao que identificamos por essa instabilidade: a violência e os estigmas. Alguns moradores respondem que não há problemas de violência, outros dizem que ficam no "cantinho deles". No entanto, os relatos sobre tiroteios são bastante frequentes. Segundo alguns moradores, não era raro a polícia recolher corpos pela manhã, ou que, à noite, às vezes parecia "bangue-bangue". Essa vivência de cotidiano, repercute nas práticas dos que ali vivem, condiciona essas pessoas a uma vida de privações, da convivência em comunidade, contribuindo em boa medida para a instabilidade territorial do local.

Essa situação colabora para a construção de um imaginário de lugar com frágeis vínculos de pertencimento e estigmatizado. Moradores já reassentados, a não mais que 50 metros dali, na Vila Bela Vista, reconstroem plenamente seus vínculos com o novo lugar e fazem questão de estabelecerem a diferença: "não, hoje não digo que moro na Vila Areia, eu moro é na Bela Vista ${ }^{20}$ ". A Vila Areia ganha ares de local de exílio e sinônimo de deterioração, como observou Wacquant (1992), para Banlieues franceses e guetos negros norte-americanos.

A Vila Chocolatão, recentemente teve a maior parte de seus moradores reassentados no bairro Mário Quintana, distante cerca de $12 \mathrm{~km}$ da área central que ocupa atualmente. Alguns não cadastrados nesse processo voltaram às ruas. Por isso que se considera que, quando ocorrem remoções das populações das áreas centrais, que se diz que se faz uma destruição da teia de relações sociais estabelecidas nessas áreas, visto que para profissões como catadores, a centralidade é uma importante fonte de recursos para a reprodução social das famílias.

A Vila Icaraí II está sendo removida e parte de seus ocupantes serão reassentados em diversas regiões da cidade em projetos de habitação popular, enquanto outros estão sendo indenizados, com o compromisso de adquirirem outro imóvel e não retornarem. Desse modo, um dos componentes mais importantes da experiência é a localização.

Forma-se dessa maneira a compreensão do significado territorial dessas ocupações: trata-se de um fato em si, a materialidade, que é produzido por atores, é resultado de um agir e se faz como tal por ter sido compreendido, em ação e

19 Relato de morador.

20 Relato de morador. 
materialidade, e ter uma representação. Ele possui enlaces com o poder, em que seu princípio básico, como compreendido por Sack (1986), é constituir-se em estratégia, alçada especialmente quando as outras formas que estruturam a ordem social não surtem efeito, como o diálogo, a política e o consenso, por exemplo. Como se pode ver, muito mais que uma restrição de acesso, os territórios produzidos são estratégia para ganhar a cidade e também garantir uma forma de reprodução social.

A busca por moradia próxima à centralidade urbana é o que motiva essas populações. Geralmente esse tipo de ocupação não se dá em grande escala, todos ao mesmo tempo e de forma organizada. É uma invasão silenciosa. A informação corre na informalidade. Essa invasão silenciosa ou apropriação silenciosa da rotina - que segundo Asef Bayat, é a apropriação de espaços marginais ou intersticiais em pequena escala e sem confronto - mostra “a invasão silenciosa dos 'comuns', um avanço silencioso, paciente, prolongado e generalizado das pessoas comuns sobre a propriedade para sobreviver às dificuldades e melhorar suas vidas" (BAYAT, 1997, p. 57). Constituem processos que têm a ver com uma escrita da cidade, "aquilo que acontece na rua, nas praças, nos vazios, aquilo que se diz aí (...) aquilo que se inscreve e se prescreve em seus muros, na disposição dos lugares e no seu encadeamento" (LEFEBVRE, 2008, p. 70), ou seja, é a maneira como as pessoas organizam o seu cotidiano, suas práticas e ideologias, espacialmente.

Por isso podemos pensar que os sujeitos desse processo são atores que se envolvem numa luta pelo espaço da cidade e constituem autênticas comunidades de vida (BERGER; LUCKMAN, 2004 [1995]), um grupo coeso e articulado, que se veem diferenciados por meio das experiências que vão tendo e, ao mesmo tempo, identificados pela geografia que produzem. E, por essa geografia, por seus territórios, torna-se possível elaborar uma fala desses em relação aos outros.

\section{ALGUMAS CONSIDERAÇÕES}

Muito se tem explorado esse tema em nossa realidade urbana, particularmente nos países em que a urbanização foi historicamente marcada por profundas desigualdades. Em especial, a compreensão do problema sob a ótica da produção do espaço urbano, das migrações campo-cidade e da lógica da reprodução do capital imobiliário renderam importantes compreensões. Nessa exposição, se buscou um foco de análise variante. A preocupação maior destas reflexões foi expor um pouco do argumento territorial para compreender certa lógica e aspectos do cotidiano da formação das áreas de ocupação irregular na cidade de Porto Alegre. A pesquisa, na qual estas reflexões se apoiam, parte de uma consideração básica, de que se soma aos processos já conhecidos, uma lógica que está ligada à propensão humana de agir territorialmente para se ganhar o espaço. 
O espaço do qual falamos é a cidade, que possui a expressão de um espaço social que contém a materialidade, os objetos e as relações com vistas à garantia dos direitos e o convívio entre desiguais, ao consumo do espaço e à reprodução de estilos de vida.

Do lado dos que almejam ter a cidade, então são alçadas estratégias que se consubstanciam em territórios - áreas de ocupação -, os quais estamos acostumados a chamar de irregulares, do ponto de vista legal. Do ponto de vista da teoria posta em uso aqui, trata-se simplesmente de ocupação. Ela constitui outros espaços sociais, que têm a cidade como meta: meios de consumo coletivo, escola, posto de saúde, oportunidades econômicas, endereço e acesso à centralidade, como já possuem os habitantes "normais" da cidade.

A leitura, então, não está focada para compreender a dominação, a explicação do espaço, mas a sua apropriação, em que as imbricações estão focadas na ordem próxima, em diálogo, ou contraposição, ao maior, ao estabelecido. A cidade não é o dominador, ela também é um construto, mas é um espaço geral em que as desigualdades são ordenadas e, por isso, ela tende a negar o acesso. Ela não dá conta do que vem por sobre o mundo que promete. Como duas estratégias antagônicas de se almejar a cidade, a que está estabelecida por meio do mercado, do plano e da gestão e a que é solicitada, por meio da ocupação, terminam por produzir, de novo, a cidade, com o plano, o mercado e a gestão. As estratégias se encontram ao final do processo produzindo o reassentamento, a remoção e a reurbanização. Os dois primeiros são em geral modos de tornar periférico o problema, de conceder a cidade parcialmente e na sua feição mais precária. A reurbanização, por sua vez, significa mais concretamente a conquista da cidade formal, da sua materialidade. Muitas vezes, porém, essa conquista vem acompanhada das taxas de direito de uso, energia elétrica e água, que nem todos os antigos ocupantes estão capacitados a consumir formalmente. Em muitos desses casos, a periferia se encontra no centro. Damos-nos por conta, então, que ganhar a cidade não é simplesmente residir nela, mas se precisaria trazer de volta a sua essência: um espaço de convívio, de mercado, de política e de civilidade, fazendo dessa ideia integralmente um fato.

\section{REFERÊNCIAS}

AGUIAR, R. C. de; HEIDRICH, A. L.; UEDA, V. Os Condomínios Horizontais e as "Diferentes Caras da Cidade” no município de Porto Alegre/RS. In: XV Encontro Nacional de Geógrafos, São Paulo: Anais do XV Encontro Nacional de Geógrafos, 2008.

AGUIAR, R. C. de; HEIDRICH, A. L. A ocupação irregular em Porto Alegre no ano de 2000. In: XXX Encontro Estadual de Geografia. Outras Geografias: entre território e ambiente, região e desenvolvimento, 2011, Erechim. Anais XXX Encontro Estadual de Geografia. Outras Geografias: entre território e ambiente, região e desenvolvimento. Erechim; Porto Alegre: UFFS; AGB, 2011. v. único. 
BAYAT, A. Un-civil society: the politics of the 'informal people'. In: Third World Quartely, London, v. 18, n. 1, p. 53-72, 1997.

BERGER, P. L.; LUCKMANN, T. Modernidade, pluralismo e crise de sentido. Petrópolis: Editora Vozes, 2004 [1995].

BONDUKI, N.; ROLNIK, R. Periferia da Grande São Paulo. Reprodução do espaço como expediente de reprodução da força de trabalho. In: MARICATO, E. (Org.) A produção da casa (e da cidade) no Brasil Industrial. São Paulo: Editora Alfa-Omega, 1979, p. 117-154.

BOURDIEU, P.. O poder simbólico. Lisboa: Difel; Rio de Janeiro: Bertrand Brasil, 1989.

DI MÉO, G. Les territorires du quotidien. Paris; Montreal: L’Harmattan, 1996, p. 17-34.

DI MÉO, G. Géographie sociale et territories. Paris: Nathan, 1998.

DI MÉO, G.; BULÉON, P.. L'espace social. Lecture géographique des societés. Paris: Armand Colin, 2007.

FERREIRA, A. B. de H. Novo dicionário eletrônico Aurélio. 3 ed. Curitiba: Editora Positivo, 2004.

FONTOURA, A. E. S. Participação, cotidiano e identidade na periferia de Porto Alegre. Cidades. Presidente Prudente, v. 5, n. 8, p. 355-384, 2008.

GAMALHO, N. P. Malocas e periferia: a produção do Bairro Restinga. In: Ateliê Geográfico, Goiânia, v. 4, n. 10, p. 122-141, 2010.

HAESBAERT, R. O mito da desterritorizaliação. Do fim dos territórios à multiterritorialidade. Rio de Janeiro: Bertrand-Brasil, 2004.

HAESBAERT, R. Dos múltiplos territórios à multiterritorialidade. In: HEIDRICH, A. L.; COSTA, B. P. da; PIRES, C.; UEDA, V. (Orgs.). A emergência da multiterritorialidade. A ressignificação da relação do humano com o espaço. Porto Alegre: Ed. da UFRGS, 2008.

HEIDRICH, A. L. Aspectos da fratura socioespacial na cidade de Porto Alegre. Scripta Nova. Revista Eletrónica de Geografía e Ciencias Sociales, Barcelona, v. XI, n. 245 (67), p. 1-9, 2007.

HEIDRICH, A. L. Faces antagônicas da segregação espacial na cidade de Porto Alegre. Revista Geográfica de América Central, San José, n. 47E, p. 1-15, 2011.

HEIDRICH, A. L.; HEIDRICH, B. B. Reflexões sobre o estudo do território. In: BUITONI, Marísia Margarida Santiago (Coord.) Geografia: ensino fundamental. Brasília: Ministério da Educação; Secretaria de Educação Básica, 2010, p. 111-134.

JUSTIÇA tem 2.364 processos de reintegração de posse em Porto Alegre. Zero Hora, Porto Alegre, 17 set. 2014. Disponível em: <http://zh.clicrbs.com.br/rs/noticias/noticia/2014/09/ justica-tem-2-364-processos-de-reintegracao-de-posse-em-porto-alegre-4599766.html $>$. Acesso em: 10 de out. de 2014.

LEDRUT, R. El espacio social de la ciudad. Buenos Aires: Amorrortu editores, 1974 [1968].

LEFEBVRE, H. O direito à cidade. São Paulo: Centauro, 2008 [1968].

LEFEBVRE, H. Espaço e política. Belo Horizonte: Editora UFMG, 2008 [1972]. 
LOJKINE, J. O estado capitalista e a questão urbana. São Paulo: Martins Fontes, 1981 [1977].

MAMMARELLA, R.; BARCELLOS, T. M de. Estrutura social e segmentação do espaço metropolitano. Um retrato da Região Metropolitana de Porto Alegre em 2000. Cadernos da Metrópole, São Paulo, n. 13, p. 133-169, 2005.

MAMMARELLA, R.; BARCELLOS, T. M de. Uma abordagem tipológica da estrutura socioespacial da Região Metropolitana de Porto Alegre. In: ALONSO, J. A. F.; MAMMARELLA, R.; BARCELLOS, T. M. (Orgs.) Território, economia e sociedade. Transformações na Região Metropolitana de Porto Alegre. Porto Alegre: FEE, 2009, p. 137-177.

MAMMARELLA, R. (Coord.) Atualização e expansão da analise da organização social dos territórios das metrópoles e a identificação das tendências de transformação de longo prazo - 1980/2000; Região Metropolitana de Porto Alegre. Porto Alegre: FEE, 2008. (Relatório de Pesquisa do Projeto Observatório das Metrópoles: território, coesão social e governança democrática).

MARICATO, E. Autoconstrução, a arquitetura possível. In: MARICATO, E. (Org.) A produção capitalista da casa (e da cidade) no Brasil industrial. São Paulo: Alfa-Omega, 1979, p. 71-93.

MORAES, A. de O. Da irregularidade fundiária. Porto Alegre: Demhab, 1999.

MORAES, A. de O. Mapa da irregularidade fundiária. Porto Alegre, Demhab: 2000.

MORAES, A. de O. Duas ou três coisas a respeito de regularização fundiária. Porto Alegre: Demhab, 2007.

PLANO DIRETOR DE DESENVOLVIMENTO URBANO AMBIENTAL. Porto Alegre: Prefeitura Municipal de Porto Alegre/Secretaria do Planejamento Municipal, 1999. 30 p. Disponível em <http://www.portoalegre.rs.gov.br/planeja/download/download.htm>. Acesso em: 18 dez. 2015.

RAFFESTIN, C. Repères pour une théorie de la territorialité humaine. Cahier/Groupe Réseaux, Caen, v.3, n. 7, 1987, p. 2-22. Disponível em: < http://www.persee.fr/doc/flux_1162-9630_1987_ num_3_7_1053>. Acesso em: 15 dez. 2015.

RIBEIRO, L. C. Q.; LAGO, L. C. do. O espaço social das metrópoles brasileiras. Revista Brasileira de Estudos Urbanos e Regionais, Recife, n. 3, 2000, p. 111-129.

SACK, R. D. Human territoriality. Its theory and history. Cambridge: Cambridge University Press, 1986.

SANFELICE, D. de M. A produção do espaço como mercadoria: novos eixos de valorização imobiliária em Porto Alegre/RS. (Dissertação de mestrado). São Paulo: USP/FFLCH, 2009. 147 p.

SAQUET, M. A. Abordagens e concepções de território. São Paulo: Expressão Popular, 2007.

SAQUET, M. A.; SPOSITO, E. (Orgs.). Territórios e territorialidades. Teorias processos e conflitos. São Paulo: Expressão Popular, 2009.

SILVA, C. E. Gestão Democrática da cidade e o direito à moradia. In: ALFONSIN, B. de M.; PAGANI, E. A.; SOMENSI, S.; PRESTES, V. B. (Orgs.). Anais do II Congresso de Direito Urbano e Ambiental: Congresso comemorativo aos 10 anos do Estatuto da Cidade. Vol. 1 Porto Alegre: Exclamação, 2011, p. 309-324. 
SOUZA, M. J. L. de. O território: sobre espaço e poder, autonomia e desenvolvimento. In: CASTRO, I. E. de; GOMES, P. C. da C.; CORRÊA, R. L. (Orgs.). Geografia: conceitos e temas. Rio de Janeiro: Bertrand-Brasil, 1995, p. 77-116.

SOUZA, M. J. L. de. Território do outro, problemática do mesmo?. In: ROSENDAHL, Z.; CORREAA, R. L. (Orgs.) Religião, Identidade e território. Rio de Janeiro: EdUERJ, 2001, 145-176.

TEIXEIRA, C. C.; SOUZA , A. C. B.; HEIDRICH, A. L. Território da ocupação: a presença da Territorialidade na vila areia, Porto Alegre. In: SILVEIRA, D. (org.). Anais XXX Encontro Estadual de Geografia. Porto Alegre: AGB-PA, 2011.

TIZON, P. Qu’est-ce que le territorire?. In: DI MÉO, Guy. Les territorires du quotidien. Paris; Montreal: L'Harmattan, 1996, p. 17-34.

WACQUANT, L. Condenados da Cidade: estudos sobre marginalidade avançada. Rio de Janeiro: Revan, 2005, 2a edição, setembro de 2005. 